\title{
Türkçe Öğretmeni Adaylarının “Hızlı Okuma” Becerisine Yönelik Metafor Algıları
}

\section{Metaphor Perceptions of Pre-Service Turkish Language Teachers towards "Speed Reading" Skills}

\author{
Ömer Kemiksiz a, \\ ${ }^{a}$ Dr. Öğr. Üyesi, Bartın Üniversitesi, Eğitim Fakültesi, Türkçe ve Sosyal Bilimler Eğitimi Bölümü, 74000, Bartın/Türkiye. \\ ORCID: 0000-0001-8628-6203
}

\section{MAKALE BILGIISI}

\section{Makale Geçmişi:}

Başvuru tarihi: 27 Mart 2018

Düzeltme tarihi: 17 Mayıs 2018

Kabul tarihi: 28 Mayıs 2018

\section{Anahtar Kelimeler:}

Okuma Becerisi

Hizlı Okuma

Metafor

Alg1

Öğretmen Adayları

\section{ARTICLE INFO}

\section{Article history:}

Received 27 March 2018

Received in revised form 17 May 2018

Accepted 28 May 2018

\section{Keywords:}

Reading Skill

Speed Reading

Metaphor

Perception

Teacher Candidates
ÖZ

Bu araştırmanın amacı, Türkçe öğretmeni adaylarının hızlı okuma becerisine yönelik algılarını metaforlar yoluyla tespit etmektir. Çalışma 2017-2018 eğitim öğretim yılı güz döneminde Bartın Üniversitesi Eğitim Fakültesi Türkçe Eğitimi Ana Bilim Dalında öğrenim gören 176 öğretmen adayı ile gerçekleştirilmiştir. Nitel araştırma desenlerinden olgu bilimin kullanıldığı araştırmanın verileri, araştırmacı tarafindan oluşturulan formlarla toplanmıştır. Veri toplama sürecinde öğretmen adaylarından bu formlarda yazılı olan "Hızlı okuma ......... gibidir, çünkü ........." ifadesindeki boşlukları doldurmaları istenmiştir. Elde edilen veriler, içerik analizi ile çözümlenmiştir. Verilerin analizi neticesinde Türkçe öğretmeni adaylarının hızlı okuma becerisine yönelik 122 farklı olmak üzere toplam 161 adet geçerli metafor ürettikleri ortaya çıkmıştır. Elde edilen bu metaforların gerekçelendirme yönleri dikkate alınarak yapılan analizler sonucu, öğretmen adaylarının oluşturdukları metaforlar 10 kavramsal kategori altında toplanmıştır.

\section{A B S T R A C T}

This study aims to determine the perceptions of pre-service Turkish language teachers towards their speed reading skills through metaphors. The study was carried out with 176 pre-service teachers at Bartın University, Faculty of Education, Department of Turkish Language Education in Fall semester of 2017-2018 academic year. Of the qualitative research designs, phenomenology was used in the study and the data were collected through the forms prepared by the researcher. In the process of data collection, the pre-service teachers were asked to fill the gaps in phrases such as "Speed reading is like ..........., because .........." The obtained data were analyzed with content analysis. At the end of the analysis of the data, it was found that the pre-service Turkish language teachers produced a total of 161 valid metaphors, 122 of which were different. According to the analysis made by taking into account the justification of these metaphors, 10 conceptual categories were formed for the metaphors produced by the participants.

\section{Giriş}

Günlük yaşam içerisinde bireyin çeşitli sebeplerle bilgi edinme ihtiyacı vardır. Kitle iletişim araçlarının artması bilgiye ulaşma yollarını çeşitlendirdiği gibi, kişilerin ihtiyaç duyduğu ve gün içerisinde karşılaşabileceği bilgilerin her geçen gün çoğalması, bilgilere en kısa yoldan en hızlı şekilde ulaşabilme zaruretini de doğurmuştur. $\mathrm{Bu}$ durum, bilgi edinme sürecinde önemli bir yeri olan okuma becerisine farklı bir boyut kazandırmış, okumanın hem daha hızlı gerçekleştirilmesi hem de okuma için harcanan zamandan tasarruf edilmesi düşüncesiyle hızlı okuma çalışmalarına son yıllarda ağırlık ve önem verilmeye başlanmıştır.

Öğrenmeyi etkileyen en önemli etkenlerden biri olan (Ünalan, 2006) hızlı okuma, "kişilerin çabukluk, kavrama ve belleme yeteneklerini geliştirerek, daha önceki okuma süresine kıyasla dakikada okudukları kelime sayısını ve anlama sayılarını artırmaları" (Ruşen, 2016: 59), "görsel algılamaya dayalı yazıların daha çok şekil ve resim olarak algılanmasını sağlayan, bilinen okuma yöntemlerinden farklı, hız odaklı bir okuma yöntemi” (Keskin, 2015: 11),

* Sorumlu yazar/Corresponding author.

e-posta: okemiksiz@bartin.edu.tr 
"gözün metin üzerinde sıçramalar yaparken beyne gönderilen resim ve sembollerin fazla duraklama yapmadan aynı anda çözümlenerek anlamlandırılması" (Şahin, 2011: 46) biçiminde tanımlanabilir. Gündüz ve Şimşek’e (2011) göre hayatın tempolu akışı içinde okumaya zaman ayırmakta güçlük çekenler için okuma hızını artırmaya yönelik geliştirilen teknikler olarak değerlendirilen hızlı okuma, okuma eyleminin etkin ve yetkin yapılması ihtiyacindan doğmuştur (Yalçın, Erdoğan-Çeltik ve Altınok, 2017).

Mevcut metinlerin çokluğu ve hızlı bilgi işlem çağı, okumayı giderek daha önemli bir beceri durumuna getirmiştir (Wardani, 2014). Basın yayın organlarının çokluğu ile dünyanın biriken bilgi kaynaklarını yavaş okuyarak takip etmenin neredeyse imkânsız hâle geldiği günümüzde, okumada hız son derece önemli bir etkendir (Arıc1, 2012). Çünkü bilgiye ulaşma ne kadar hızla gerçekleşirse bilginin işlevselliği de o oranda artar (Şahin, 2016). Yoğun dikkat isteyen ve beyin gücümüzü maksimum düzeyde kullanmamızı gerektiren (Maviş, 2011) okuma da, hıza ve anlamaya dayalı bir beceridir (Tunalı, 2010). Bu sebeple hizlı okuma becerisinden bahsederken yalnızca "hız" faktörünü öne çıkarıp "anlama”yı ihmal etme gibi yanlış bir anlayışa düşülmemelidir. Şahin’e (2011) göre hızlı okumada amaç, belirli bir sürede daha fazla sözcük okumak değil, okunanın anlaşılması olmalıdır. Arat ve Turgut'a (2011) göre hızlı okuma faaliyeti sırf hızlı okumak için değil, aynı zamanda okumak ve düşünmek için yapılmalıdır. Aksi takdirde kişinin okuma hızının çok üstünde bir performansla okumaya çalışması, okuma faaliyetini anlamsız hâle getirir. Soysal'a (2015) göre hızlı okuma çalışmalarında okuma hızı ve anlama düzeyi birbirini destekler şekilde artmalıdır. Çalışmalarda yalnızca okuma hızına yoğunlaşılması doğru değildir. Bu yüzden hızlı okuma çalışmalarına başlandığında okuma hızının kademeli olarak artmasını, anlama düzeyinin artışı takip etmelidir. Okumanın hızlanmasının, kavrama oranı yükselmedikçe anlamlı olmayacağını vurgulayan Keskin'e (2015) göre ise hız, yeterli bir şekilde kavrama hızı olarak düşünülmeli, bu nedenle kavrama ile birlikte ele alınmalıdır. Zira bireyin hayatı boyunca başarılı olmasını sağlayan alma, yorumlama ve tepki verme sürecinin başarısını ölçme işlemi, okuma hızı ile okuduğunu anlama düzeyi üzerinde odaklanır (Saracaloğlu, Dedebali ve Karasakaloğlu, 2011).

Hızlı okumanın öğretilebileceği düşüncesinde olan Harris ve Sipay (1990; akt. Akyol, 2006), bunun için öncelikle karşımızdaki öğrenci kitlesinin bazı özelliklerini bilmek zorunda olduğumuzu dile getirmektedir. Bu tür eğitimlerde çocuklar hızlı okuma- anlama ilişkisi açısından karşımıza "anlaması ve okuma hızı orantılı", "anlaması normal, okuma hızı düşük", "okuma hızı normal, anlaması düşük" ve "okuma hızı ve anlaması düşük" olmak üzere farklı şekillerde gelebilirler. Okullarda veya çeşitli kurslarda verilen hızlı okuma teknikleri eğitimi öncesinde kursa katılanların seviyesini bilmek bu noktada önem taşır. Aksi takdirde henüz okuma konusunda bile yeterliliğe sahip olmayan birinden hızlı okumasını beklemek beyhude bir uğraş olmanın ötesine geçemez. Gündüz ve Şimşek'e (2011) göre hızlı okuma becerisi, gözün görme alanını genişleterek sayfayı bir bütün olarak görme, gözü tembellikten kurtarma ve algılama hızını artırma alıştırmalarıyla geliştirilebilir. Hızlı okuma eğitiminde gözün aktif görme alanının geliştirilmesi, gözün metin üzerinde odaklamalar yapacağ yerlerin öğretilmesi, göz hareketlerinin hızlandırılması gibi daha çok fiziksel çalıșmaların öncelikli olduğunu belirten Çiftçibaşı (2013), bunun yanında çabuk algılamanın sağlanması için gerekli bilişsel çalışmaların da sürece dâhil edilmesi gerektiğine inanmaktadır. Kondu (2010), hızlı okuma eğitiminin okurun, görsel algılama düzeyini geliştirerek okuma, algılama, anlama düzeylerini yükseltmeyi hedeflemesi gerektiğini ifade ederken Calp'e (2010) göre hızlı okuma konusunda verilecek eğitim sadece okuma hızını artırmayı amaçlamakla kalmamalı, kavramanın geliştirilmesi ve istenilen bilgilerin sistemli bir şekilde uzun süreli hatırlanmasını sağlayacak yöntem ve tekniklerin öğretilmesini de hedeflemelidir. Hızlı okuma öğretiminde üzerinde durulması gereken alt alanlara vurgu yapan Güneş'e (2009) göre ise bu alanlar, hızlı okuma çalışmalarına başlamadan önce okumayı engelleyen veya olumsuz etkileyen etkenleri ortadan kaldırma, görme çabukluğunu geliştirme, kelimeleri hızlı tanıma ve doğru okuma, dikkati toplama ve sürdürme, görme yelpazesini genişletme, göz duruşlarını ve hızını düzenleme, gözün gereksiz hareketlerini azaltma, anlama ve zihinde yapılandırma hız ve düzeyini artırma, tam okuma yöntemlerini uygulama, seçmeli okuma yöntemlerini uygulama, metni tanıma, metin türlerini ve yapılarını keşfetme, görselleri okuma ve ekrandan okuma becerilerini geliştirme, hızlı okuma yöntem ve tekniklerini çeşitli metinlere uygulama biçiminde sıralanmaktadır.

Hızlı okuma alanında verilen eğitimlerden kısa sürede yüksek derecede verim beklememek gerekir. Coşkun'a (2002) göre hızlı okuma eğitimi kapsamında gerçekleştirilen çalışmaların verimliliği insanların yaşına, zekasına, genel yetenek ve kültürüne, okuma anındaki motivasyon ve dikkatine, metin hakkındaki ön bilgisine bağlı olarak değişebilmektedir. Bununla birlikte her metnin aynı hızda okunması da mümkün değildir. Okuma hızı, metnin özelliklerine göre değişiklik gösterebildiği gibi (Gündüz ve Şimşek, 2011) aynı yazının değişik bölümlerine göre de esneklik gösterebilir (Ruşen, 2016). Okuma amacı ve okunan metnin türü (Karatay, 2014), metnin sürükleyiciliği, sözcüklerin açık ve anlaşılır olması, okuyucunun metne olan tutumu (Şahin, 2011), metinlerin güncel olup olmaması ve zorluk düzeyi (Arıc1, 2012), seslendirerek ya da dudak kıpırdatarak uygulanan okuma işlemi, gözlerin sözcük kümeleri ya da satır üzerinde durması yerine her sözcük üzerinde durması, anlayamama kaygısıyla okunan sözcükleri geri dönüp bir kez daha okuma, gereksinim ve amaç saptamadan uygulanan pasif okuma (Kayalan, 2000), bilgi dağarcığının yeterince geniş olmaması, konsantrasyonun az olması, ilgi ve isteğin yeterli olmaması (Döğüşgen, 2017), geri dönüş ve ayrıntılara takılma, hızlı okursam anlayamam inanc1, göz idmansızlığı, bilgi ve kültür düzeyi eksikliği, dil bilgisi ve kelime dağarcı̆̆ 1 yetersizliği, dikkatin okunan yazıya yeterince yöneltilmemesi (Ruşen, 2016) gibi daha birçok unsur, kişinin metni okuma hızını dolayısıyla da anlama/kavrama düzeyini etkileyebilir.

Düşünme hızını artırarak anlama düzeyini ve algılama becerisini geliştiren, araştırma ve inceleme çalışmalarında kısa sürede daha çok bilgiye ulaşılmasını sağlayan (Ünalan, 2006), bireye aynı okuma süresi içinde daha çok okuma imkânı sunan, daha çok zamana sahip olma ve daha iyi anlama/hatırlama firsatı sağlayan, profesyonel iş hayatında, okul hayatında daha başarılı olmayı, bilgi çağı adı verilen yeniçağa ayak uydurabilecek bilgi ve kültür düzeyine daha çabuk ulaşabilmeyi sağlayan, karar verme ve intikal 
yeteneğini artıran (Dedebali, 2008) hızlı okumanın önemi her geçen gün daha da artmaktadır. Ancak artan bu öneme karşın bu konuda ülkemizde yapılan çalışmaların sınırlı sayıda olduğunu söylemek de mümkündür. Bu çalışmalar ise daha çok okuma hızı-anlama düzeyi arasındaki ilişkiyi ortaya koymaya dönüktür. Bozan (2012) tarafından yapılan araştırmada ortaöğretim 10. sınıf öğrencilerine verilen hızlı okuma eğitiminin, Dedebali (2008) tarafindan yapılan araştırmada 8. sınıf öğrencilerine verilen hızlı okuma eğitiminin, Soysal (2015) tarafından gerçekleştirilen araştırmada 5. sınıf öğrencilerine verilen hılı okuma eğitiminin, Yalçın, Erdoğan-Çeltik ve Altınok (2017) tarafindan yapılan araştırmada ise hukuk fakültesi 1. sınıf öğrencilerine verilen hızlı okuma eğitiminin, öğrencilerin okuma hızlarına ve anlama düzeylerine olan etkisi incelenmiş, yapılan çalışmalar sonucunda hızlı okuma eğitiminin öğrencilerin okuma hızlarına ve okuduğunu anlama düzeylerine olumlu etkilerinin olduğu görülmüştür.

Kaçar'ın (2015) araştırmasında hızlı okuma eğitiminin ortaokul 7. sınıf öğrencilerinin okuduğunu anlama becerilerine ve okumaya ilişkin tutumlarına etkisi ortaya konulmuştur. Coşkun'un (2002) araştırmasında lise 2. sınıf öğrencilerinin sessiz okuma hızları ile anlama düzeyleri arasındaki ilişki incelenmiştir. Saracaloğlu, Dedebali ve Karasakaloğlu (2011) tarafindan yapılan ve sessiz okuma hızı ile anlama düzeyi arasındaki ilişkinin ele alındığı bir diğer araştırmada ise 8. sınıf öğrencileri ile çalışılmıştır. Başaran (2014), kâğıttan ve ekrandan okumanın ilkokul 4. sınıf öğrencilerinin okuma hızlarına ve buna bağlı olarak okuduğunu anlama düzeylerine etkisini araştırmıştır. Şahin'in (2016) araştırmasında ilkokul öğrencilerinin okuma hızlarına dik ve bitişik eğik yazı ile yazılmış metinlerin etkisinin olup olmadığı ele alınmıştır. Keskin ve Akyol'un (2014) çalışmasında yapılandırılmış okuma yönteminin 4 . sınıf öğrencilerinin okuma hızlarına olan etkisi incelenmiştir. Çiftçibaşı'nın (2013) çalışmasında ise hızlı okuma teknikleri eğitiminin müzik öğretmeni adaylarının deşifre becerilerine etkisi araştırılmıştır.

$\mathrm{Bu}$ araştırmada Türkçe öğretmeni adaylarının hızlı okuma kavramına yönelik algıları metaforlar yoluyla tespit edilmeye çalışılmış, böylece bu beceriyle ilgili literatüre farklı bir açıdan katkı sunmak amaçlanmıştır.

Bilgi ile duygu arasında köprü kuran (Modell, 2009) ve "bilinmeyeni anlamak ve açıklamak için bilinmeyenin bilinenle benzer özelliklerinden yararlanma biçiminde işleyen bir düşünüş tarzı" (Aydeş ve Akın, 2016: 21), öğrenilenlerin, daha önceden bilinen ilgisiz bir olaya ya da nesneye benzetilmesi (Ün-Açıkgöz, 2007), "bir konuyu diğer bir konunun bakış açısından algılamaya ve anlamaya izin veren zihindeki bilgiler arasında bir bağ kurma süreci" (Eraslan, 2011: 4), iki olgu, olay veya nesneyi karşılaştırarak bunlardan birinin bilinen özelliklerinden hareket ederek diğerinin özellikleri hakkında fikir beyan etme (Köksal ve Atalay, 2016) şeklinde tanımlanan metafor, Palmquist (2001) tarafından iki nesne veya kavramı birbirine bağlayan dilsel araçlar, Woollard (2005) tarafindan ise bilişimizin, anlayışımızın ve düşüncemizin bir parçası olarak kabul edilir.

Karmaşık ve soyut bir olguyu anlamada ve açıklamada güçlü zihinsel araçlar (Yob, 2003) olarak kabul edilen metaforlar, analiz edilmek istenen olgu, olay ve kavramlarının nasıl algılandığını ortaya çıkarmada (Aydın, 2011; Cerit, 2008;
Ünal, 2017; Yalçın ve Erginer, 2012), bireylerde var olan zihinsel imgelerin ortaya çıkarılmasında (Taşgın ve Köse, 2016), bireylerin yaşam algılarını ortaya koyup onların dünyayı ve kendilerini algılama biçimlerinin anlaşılmasında (Dündar ve Karaca, 2013; Pilav ve Elkatmış, 2013), kavramların analiz edilmesinde, yaşama yakınlık sağlayarak anlaşılır duruma getirilmesinde, deneyimlerin aktarılmasında, duygu ve düşüncelerin paylaşılmasında (Aykaç ve Çelik, 2014), soyut fikirleri somut imajlarla ilişkilendirmede (Sterenberg, 2008), anlaşılması zor kavramların benzetme yoluyla bilinen kavramlarla anlatılmasında (Geçit ve Gencer, 2011), bilinen bir alandan yeni/bilinmeyen bir alana bilgi transferinin gerçekleştirilmesinde (Güveli, İpek, Atasoy ve Güveli, 2011) oldukça etkili araçlar olduğundan son yıllarda farklı disiplin alanlarındaki çalışmalarda sıklıkla tercih edilmektedir.

Bireye iki olay, olgu, konu ya da kavram arasında karşılaştırma yapma ve bunlar arasındaki benzerlikleri mecazlı bir anlatımla sunma imkânı sağlayan metaforlar, böylece iki şey ile ilgili benzerliklere dikkat çeker ya da birini diğerinin yerine geçirerek açıklama fırsatı verir (Coşkun, 2010). Böylelikle metaforlar, hem okuyucuda hem de dinleyicide bilişsel bir sürecin başlamasını sağlar. Bilişsel sürecin gelişmesi ise bireyde duyuşsal etkiler yaratır. Böylece bilişsel ve duyuşsal süreçler karşılıklı olarak birbirini etkiler ve besler (Girmen, 2007). Bireyin zihninin belli bir kavrayış biçiminden başka bir kavrayış biçimine doğru yönelmesini sağlayan metaforlar, o bireyin belli bir olguyu başka bir olgu olarak görmesine olanak tanır (Saban, 2009) ve böylece bireylerin hayal güçlerini de kullanarak kendilerini ifade edebilme ve olaylara farklı açılardan bakabilme niteliklerinin gelișmesine katkıda bulunur (Taşdemir, 2013). Ekici’ye (2016) göre bireylerin yaratıcılıklarının, gözlemlerinin, tecrübelerinin, bilgi birikimlerinin ve kültürel değerlerinin oldukça değerli ürünleri olan metaforlar, Yalçın, Aydoğdu-Özoğlu ve Dönmez'e (2016) göre eylemler ve düşüncelerin zihinsel birer imge olmaktan çıkıp kavramsallaşmaları sürecinin yapıtaşları olarak içinde bulunulan ortam ve kültürün bir yansıması niteliğindedir.

İletişim aracı olmasının yanı sıra bireylerin kişisel deneyimlerine yön vermede de önemli bir araç (Ekiz ve Koçyiğit, 2013) olan metaforların, eğitim öğretim çalışmalarında kullanılmasının çeşitli yönlerden hem katılımcılara hem de araştırmacılara faydalı olduğu söylenebilir. Çelikten (2006), metaforların eğitim araştırmalarında imajların oluşturulmasında ve yeniden yapılandırılmasında, eğitim faaliyetlerinde ihtiyaçların belirlenip anlamlandırılmasında yardımcı olacağını ifade eder. Bektaş, Okur ve Karadağ'a (2014) göre çeşitli benzetmeler yoluyla geliştirilen metaforlarla araştırılan konunun öğrencilerin dünyasında nasıl yer aldığı hakkında bilgi edinilebilir. Edinilen bu bilgiler de gelecekteki eğitimcilere ve araştırmacılara o konuda neler yapılması gerektiği konusunda rehberlik yapabilir. Arslan ve Bayrakçı (2006), metaforun bir öğretim aracı olarak en önemli yönlerinden birisinin uzun dönem akılda tutmayı sağlayıcı bir ortam yaratabilmesi olduğunu vurgularken Koç'a (2014) göre metaforlar, yürütülen çalışmaları tekdüze ve sıkıcı bir yapıdan kurtarmakta, alışılagelmiş tekniklerin dışında yeni bir alternatif oluşturma, yaratıcı düşünmeyi destekleme, farklı bakış açılarını ortaya koyma imkânı sunmakta ve belli 
başlı sınırlar çerçevesinde değil tamamen bireylerin düşünce sistemine göre ilerleyen özgürlükçü bir çalışma ortamı sağlamaktadır. Metafor kullanımın öğrencilerin zihinlerinde var olan kavramlarla yeni öğrenmek durumunda oldukları kavramı eşleştirerek öğrenmesini kolaylaştırdığını vurgulayan Ekici’ye (2016) göre böylece öğrenciler, zihinlerinde kendilerine göre bir şema oluşturmakta, konuyu basitleştirmekte ve soyut kavramları somutlaştırabilmektedirler. Öğrenciler tarafından üretilen metaforların ilgi çekici, uçuk, komik, renkli, sesli vb. olması gibi farklı özellikler barındırması öğrenmedeki kalıcılığı artırdığ1 (Taşdemir, 2013) gibi öğrencilerin derse olan ilgilerini artırmada ve kavram yanılgılarının düzeltilmesinde (Komisyon, 2014) de önemli bir yeri vardır.

Metafor çalışmalarının araştırmacılar için olumlu yönlerine değinen Yıldırım ve Şimşek'e (2011) göre metaforlar, farklı sözcüklerden oluştuğundan ayrıştırılmaları araştırmacılar için bir sorun oluşturmamaktadır. Aynı zamanda metaforları benzerlik ve farklılık anlamında belirli tematik başlıklar altında toplamak da oldukça kolaydır. Bütün bu göreli basitlik ve kolaylığın yanı sıra metaforlar çalışılan konu, olgu, olay ve durum hakkında araştırmacılara çok sağlam, zengin bir resim sunar ve görsel bir imaj sağlar.

Öğrencilerin dil becerilerinin geliştirilmesinde öncelikle bu becerilere olan tutum ve algılarının belirlenmesi önem taşımaktadır. Metafor çalışmalarının öğrencilerin temel dil becerilerine karşı algısını ortaya koymada etkili olacağ düşüncesinden hareketle alan yazında farklı çalışmalar ortaya konulmuştur. Türkçe eğitimi alanında temel dil becerileri (okuma, yazma, konuşma, dinleme) üzerine gerçekleştirilen metafor çalışmalarında bu becerilerin tamamını içeren araştırmalar (Bozpolat, 2015; Lüle-Mert, 2013; Ulusoy, 2013) yanında ilk okuma yazma (Köksal, Erginer ve Baloğlu, 2016; Susar-Kırmızı ve Çelik, 2015), okuma (Karakuş ve Kozçetin, 2016), ekran okuma (Azizoğlu ve Okur, 2018), yazma (Baki ve Karakuş, 2017; Erdoğan ve Erdoğan, 2013; Müldür ve Çevik, 2017; Tiryaki ve Demir, 2016), eleştirel yazma (Topçuoğlu-Ünal ve Tekin, 2013) ve konuşma (Akkaya, 2011) becerilerini özel olarak ele alan araştırmalara da rastlanmaktadır.

Türkçe öğretmeni adaylarının hızlı okuma becerisine yükledikleri anlamları metaforlar yolu ile tespit etmeyi amaçlayan bu çalışmada aşağıdaki sorulara cevap aranmıştır:

(i) Türkçe öğretmeni adaylarının hızlı okuma becerisine yönelik oluşturdukları metaforlar nelerdir?

(ii) Türkçe öğretmeni adaylarının hızlı okuma becerisine yönelik oluşturdukları metaforlar hangi kategoriler altında toplanabilir?

(iii) Türkçe öğretmeni adayları tarafından oluşturulan metaforlar sonucu ortaya çıkan kavramsal kategorilerin olumluluk-olumsuzluk özelliklerine göre dağılımı nasıldır?

\section{Yöntem}

Araştırmanın bu bölümünde araştırma modeli, çalışma grubu, veri toplama arac1, verilerin toplanması ve analizi hakkında bilgiler verilecektir.

\section{1. Araştırmanın Modeli}

$\mathrm{Bu}$ araştırmada nitel araştırma desenlerinden olgu bilim (fenomenoloji) kullanılmıştır. Olgular yaşadığımız dünyada olaylar, deneyimler, algılar, yönelimler, kavramlar ve durumlar gibi değişik biçimlerde karşımıza çıkabilmektedir. Olgu bilim ise farkında olduğumuz ancak derinlemesine ve ayrıntılı bir anlayışa sahip olmadığımız olgulara odaklanan bir desen olarak kullanılmaktadır (Yıldırım ve Şimşek, 2011). Genelleme yapmanın değil olguları tanımlamanın önemli olduğu bu desende araştırmacı, katılımcıların tecrübeleri, algılamaları ve olaylara yükledikleri anlamlarla ilgilenmektedir (Akturan ve Esen, 2008).

\section{2. Çalışma Grubu}

Bu araştırma, 2017-2018 eğitim öğretim yılı güz döneminde Bartın Üniversitesi Eğitim Fakültesi Türkçe Eğitimi Ana Bilim Dalında öğrenim gören 1., 2., 3. ve 4. sınıf öğrencileriyle gerçekleştirilmiştir. Amaçlı örnekleme çeşitlerinden kolay ulaşılabilir durum örneklemesinin kullanıldığı araştırmaya katılan sınıflara yönelik sayısal bilgiler Tablo 1'de gösterilmiştir.

Tablo 1. Çalışma Grubuna Yönelik Sayısal Bilgiler

\begin{tabular}{lcc}
\hline Sinıf Düzeyi & f & $\%$ \\
\hline 1. Sinıf & 53 & $\% 30.11$ \\
2. Sinıf & 55 & $\% 31.25$ \\
3. Sinıf & 38 & $\% 21.59$ \\
4. Sinıf & 30 & $\% 17.05$ \\
\hline Toplam & 176 & $\% 100$ \\
\hline
\end{tabular}

Tablo 1'de görüldüğü gibi araştırmaya 1 . sınıf seviyesinden 53,2 . sinif seviyesinden 55, 3. sinıf seviyesinden 38 ve 4 . sınıf seviyesinden 30 olmak üzere toplamda 176 Türkçe öğretmeni adayı katılmıştır.

\section{3. Veri Toplama Arac1}

Araştırmanın verilerini toplamak amacıyla uzman görüşleri doğrultusunda araştırmacı tarafından oluşturulan formlardan yararlanılmıştır. Bu formlarda yazılı olan "Hızlı okuma ................ gibidir, çünkü ..............." cümlesinden hareketle katılımcıların hızlı okuma becerisine yönelik oluşturdukları metaforlar da çalışmanın veri kaynağını oluşturmuştur.

\section{4. Verilerin Toplanmasi}

Uygulama öncesinde katılımcılara metafor uygulamaları hakkında bilgilendirme yapılmış ve farklı metafor örnekleri sunulmuştur. Daha sonra araştırma formları kendilerine dağıtılmıştır. Türkçe öğretmeni adaylarının hızlı okuma becerisine yönelik algılarını belirlemek için onlardan formlarda yazılı olan "Hızlı okuma .................... gibidir, çünkü ................" şeklinde oluşturulan cümleyi tamamlamaları istenmiştir. Metafor çalışmalarında sıklıkla karşımıza çıkan bu yöntemde, cümlenin ilk kısmında yer alan “... gibidir" ifadesi ile bir benzetmenin oluşturulması, ikinci kısmında yer alan "çünkü ..." ifadesi ile de oluşturulan bu benzetmenin mantıklı bir sebebe dayandırılmasi/gerekçelendirilmesi hedeflenmektedir. Uygulamada ögretmen adaylarından ilgili beceriyle ilgili tek bir metafor oluşturmaları istenmiş ve bu işlem için kendilerine yeterli süre tanınmıştır. Böylece Türkçe 
öğretmeni adaylarının hızlı okuma becerisine yönelik algılarını hangi metaforlarla ortaya koydukları, bu metaforların gerekçeleri ve ortak özellikleri belirlenmeye çalışılmıştır. Katılımcıların kendi el yazılarıyla oluşturdukları metaforlar, bu araştırmanın temel veri kaynağı olarak kullanılmıştır.

\section{5. Verilerin Analizi}

Araştırma verilerinin değerlendirilmesinde nitel araştırma desenine uygun olarak içerik analizinden yararlanılmıştır. Yazıl1, sözlü bir metnin veya sembolün analiz edilerek rakamlara dönüştürülmesi ve bu rakamlar üzerinden yoruma gidilmesi (Şahin, 2010) biçiminde tanımlanabilecek içerik analizinde temel amaç, toplanan verileri açıklayabilecek kavram ve ilişkilere ulaşmaktır. Bu amacı gerçekleştirmek için toplanan verilerin önce kavramlaştırılması, ardından ortaya çıkan kavramlara göre mantıklı şekilde düzenlenmesi ve buna göre veriyi açıklayan temaların saptanması gerekir (Yıldırım ve Şimşek, 2011). Bu süreç, verilerin kodlanması, temaların bulunması, kodların ve temaların düzenlenmesi, bulguların toplanması ve yorumlanması olmak üzere dört adımda gerçekleşir (Merriam, 2013).

Türkçe öğretmeni adaylarının hızlı okuma becerisine yönelik oluşturdukları metaforların analizinde Saban (2009) tarafından belirlenen işlem basamakları (kodlama ve ayıklama aşaması, örnek metafor imgesi derleme aşaması, kategori geliştirme aşaması, geçerlik ve güvenirliği sağlama aşaması ve metaforları nicel verilere aktarma aşaması) kullanılmıştır.

Kodlama ve Ayıklama Aşaması: Bu aşamada öncelikle öğretmen adaylarından toplanan formlar, sınıf düzeylerine göre tasnif edilmiş ve numaralandırılmıştır. Katılımcıların ürettikleri metaforlar, alfabetik sırayı gözeterek bilgisayar ortamına aktarılmıştır. Oluşturulan liste "metafor-gerekçekatılımcı bilgisi" olmak üzere üç başlıktan meydana gelmiştir. Her bir metafor ve gerekçesinin karşısına o metaforu oluşturan katılımcının sınıf seviyesi ve form üzerindeki sıra numarası yazılmıştır. Katılımcıların geçerli bir metafor üretebilmesi, ürettiği metaforu gerekçelendirebilmesi, açık ve anlaşılır biçimde dile getirebilmesi araştırmanın temel amacı olduğundan bu ölçütlere uygun bulunmayan 15 adet form elenerek çalışmanın dışında bırakılmıştır. Geri kalan 161 formun sınıflara göre dağılımı $1 . \sin ı f=48,2 . \operatorname{sinıf}=47,3$. sınıf $=36$ ve 4. sinıf $=30$ şeklinde gerçekleşmiştir.

Örnek Metafor Imgesi Derleme Aşaması: Geçersiz formların araştırma dışında bırakılmasının ardından geçerli 161 metafor gerekçeleriyle birlikte listelenmiş, ortaya 122 farklı metafor çıkmıştır. Metaforların belli kategoriler altında toplanmasında başvuru kaynağı olarak kullanmak, yapılan araştırmanın veri analiz sürecini ve yorumlarını geçerli k1lmak (Saban, 2008) amaciyla metaforları temsil eden katılımcı formlarından örnek metafor listesi oluşturma yoluna gidilmiştir. Verilen metafor gerekçelerinin kime ait olduğunu belirtmek için ilgili katılımcının sınıf seviyesi ve sınıf içindeki form sıra numarası listede belirtilmiştir. Örneğin 2. sinıfta 15 numaralı formun ait olduğu katılımcının "metafor-gerekçe" örneği 2S-15 şeklinde kodlanmıştır. Kodlamada katılımcıların uygulama sonrasında formları teslim ettikleri sıralama esas alınmıştır.
Bu kodlardan bulgular bölümünde metaforlara yönelik örnek ifadeler verme aşamasında da yararlanılmıştır.

Kategori Gelişstirme Aşaması: $\mathrm{Bu}$ aşamada öğretmen adaylarının ürettikleri metaforlar ve gerekçelendirme yönleri tekrar incelenmiştir. Metaforlar "konu, kaynak, konu-kaynak ilişkisi" açılarından ele alınmış, oluşturulan kodlardan hareketle çeşitli kategoriler elde edilmiştir. Bu noktada metaforların katılımcılar tarafından nasıl gerekçelendirildiği/ algılandığı sorusu üzerinde durulmuş, metaforlar kategorilere dağıtılırken bu ayrıma dikkat edilmiştir. Çünkü bu tür araştırmalarda aynı metaforu kullanan iki ayrı katılımcinın bu metaforu farklı şekillerde gerekçelendirmeleri söz konusu olabilmektedir. Yapılan işlemin ardından öğretmen adaylarının hızlı okuma becerisine dair ortaya koydukları metaforlar 10 kavramsal kategori altında toplanmıştır.

Geçerlik ve Güvenirliği Sağlama Aşaması: Bu aşama, nitel çalışmaların önemli basamaklarından biridir. Yıldırım ve Şimşek'e (2011) göre nitel bir araştırmada verilerin ayrıntılı biçimde rapor edilmesi ve araştırmacının sonuçlara nasıl ulaştığını açıklaması geçerliğin önemli ölçütleri arasında yer almaktadır. Bu çalışmada geçerliği sağlama adına veri toplama ve toplanan bu verilerin analiz edilmesi aşamaları ayrıntılı olarak anlatılmış, katılımcılardan alınan ifadeler bulguların sunulmasında temel veriler olarak kabul edilmiştir. Araştırmanın güvenirliğini sağlamak amacıyla araştırmacı tarafından 10 kavramsal kategori altında toplanan metaforların ilgili kategoriyi temsil edip etmediği belirlenmeye çalışılmış, bu amacı gerçekleştirmek için uzman görüşüne başvurulmuştur. Araştırmaya katkı sunacak uzmana kavramsal kategorilerin yer aldığı liste ile metaforların bulunduğu liste verilmiş, kendisinden metaforları hiçbiri dişarıda kalmayacak şekilde kavramsal kategorilerle eşleştirmesi istenmiştir. Uzman tarafindan yapılan eşleştirmeler, araştırmacının eşleştirmeleri ile kıyaslanmış, Miles ve Huberman'ın [(Güvenirlik= Görüş Birliği// (Görüş Birliği+ Görüş Ayrılığı)X 100] formülü kullanılarak görüş birliği ve görüş ayrılığı sayıları tespit edilmiştir. Gerçekleştirilen işlem neticesinde araştırmacı ile uzman arasındaki uyumun \% 91 [(148/ $(148+13)=0,91]$ olduğu sonucuna ulaşılmıştır. Miles ve Huberman'a (1994) göre uzman ve araştırmacı değerlendirmeleri arasındaki uyumun \% 90 ve üzeri olduğu durumlarda arzu edilen düzeyde bir güvenirlik sağlanmış olmaktadır (Saban, 2008). $\mathrm{Bu}$ sonuca göre araştırma sonuçlarının güvenilir seviyede olduğu düşünülmektedir.

Metaforları Nicel Verilere Aktarma Aşaması: Araştırma sonucunda ulaşılan 122 farklı olmak üzere toplam 161 metafor 10 kategori altında tasnif edilmiştir. Bilgisayar ortamına aktarılan metafor ve kavramsal kategorilerin frekansları (f) ve yüzdeleri (\%) bulgular kısmında tablolar ve grafikler yardımıyla aktarılmıştır.

\section{Bulgular}

Araştırmanın "Türkçe öğretmeni adaylarının hızlı okuma becerisine yönelik oluşturdukları metaforlar nelerdir?" şeklindeki birinci sorusuna yönelik bulgular Tablo 2'de gösterilmiştir. 
Tablo 2. Türkçe Öğretmeni Adaylarının Hızlı Okuma Becerisine Yönelik Oluşturdukları Metaforlar

\begin{tabular}{|c|c|c|c|}
\hline Metafor & $\mathrm{f}$ & Metafor & $\mathrm{f}$ \\
\hline Acele yapılan iş & 1 & Nehir & 1 \\
\hline Ac1 biber & 1 & Oksijen & 1 \\
\hline Alt yazılı film izlemek & 1 & Otobüse yetişmek & 1 \\
\hline Araba sürmek & 4 & Öğrenci & 1 \\
\hline Araba yarış1 & 1 & Motor & 1 \\
\hline Ar1 & 1 & Motosiklet & 1 \\
\hline Aşk & 2 & Namludan çıkan kurşun & 1 \\
\hline Atanamamış öğretmen & 1 & Nar & 1 \\
\hline At başı gitmek & 1 & $\begin{array}{l}\text { Nasrettin Hoca'nın eşeğe ters } \\
\text { binmesi }\end{array}$ & 1 \\
\hline Atletizm & 1 & Nehir & 1 \\
\hline At yarışçısı & 1 & Oksijen & 1 \\
\hline At yarış1 & 4 & Otobüse yetişmek & 1 \\
\hline Bisiklet sürmek & 1 & Öğrenci & 1 \\
\hline Boşa verilen emek & 1 & Parkur koşmak & 1 \\
\hline Çakal & 1 & Problem çözmek & 1 \\
\hline Çı̆̆ & 1 & Saat & 1 \\
\hline Çikolata & 1 & Saat kurmak & 1 \\
\hline Çita & 1 & Sağanak yağmur & 2 \\
\hline Dağ & 1 & Sel & 2 \\
\hline Daktiloda yazı yazmak & 1 & Serdar Ortaç şarkıları & 1 \\
\hline Demir & 1 & Sıcakta içilen 1lık su & 1 \\
\hline Depar atmak & 1 & Simit oyunu & 1 \\
\hline Doğan (araba) & 1 & Soğuk balkonda sigara içmek & 1 \\
\hline Dünya & 1 & Son dakika golü & 1 \\
\hline E-postanın icadı & 1 & Spor & 1 \\
\hline Egzersiz & 1 & $\mathrm{Su}$ & 5 \\
\hline Ekşi yüz & 1 & Sunum yapmak & 1 \\
\hline Elektrikli süpürge & 1 & Şalgam içmek & 1 \\
\hline Eti Tutku & 1 & Şelale & 2 \\
\hline Et makinesi & 1 & Rap müzik & 4 \\
\hline Eyeliner çekmek & 1 & Road Runner & 1 \\
\hline Filmin özetini izlemek & 1 & Roket & 1 \\
\hline Fotoğrafa bakmak & 1 & Ronaldo & 1 \\
\hline Fotoğraf çekmek & 1 & Rüya & 2 \\
\hline Göz & 1 & Taramalı tüfek & 1 \\
\hline Gürül gürül akan su & 1 & Tarla & 1 \\
\hline Hafta sonu & 1 & Tatil & 1 \\
\hline $\begin{array}{l}\text { Hayal kuramayan siradan } \\
\text { insan }\end{array}$ & 1 & Tavşan & 1 \\
\hline Hızlandırılmış ses kaydı & 1 & Tekerleme & 1 \\
\hline Hizlı giden araba & 3 & $\begin{array}{l}\text { Telgraf makinesinde hızlı } \\
\text { yazı yazmak }\end{array}$ & 1 \\
\hline Hizlı koşan at & 1 & Tespih & 1 \\
\hline Hizlı koşan sporcu & 1 & Timsah & 1 \\
\hline Hizlı tren & 2 & Trafik kazası & 1 \\
\hline Hızlı yaşamak & 1 & Trafik lambaları & 1 \\
\hline Hizlı yemek yemek & 4 & Tren & 1 \\
\hline Iş1k & 1 & Trene bakan öküz & 1 \\
\hline Işık hızı & 1 & Tuzsuz yemek & 1 \\
\hline İlaç & 1 & Tünel & 1 \\
\hline İmgeli şiir & 1 & Uçak & 4 \\
\hline İnsanları tanıma & 1 & Uzaydan dünyaya bakmak & 1 \\
\hline İnşaat & 1 & X-ray cihazı & 1 \\
\hline $\begin{array}{l}\text { Kalemin tahtada çıkardığı } \\
\text { ses }\end{array}$ & 1 & Volkan Demirel & 1 \\
\hline Kaplumbağa & 1 & $\begin{array}{l}\text { Yabancı dilde konuşan } \\
\text { insanları dinlemek }\end{array}$ & 1 \\
\hline Karınca & 1 & Yanlış yola girmiş araba & 1 \\
\hline Kasırga & 1 & Yapboz & 1 \\
\hline $\begin{array}{l}\text { Kaynar çayı tek nefeste } \\
\text { içmek }\end{array}$ & 1 & Yarış & 2 \\
\hline Keman yayı & 1 & Yarış arabası & 3 \\
\hline Kum saati & 1 & Yarış atı & 6 \\
\hline $\begin{array}{l}\text { Kum saatinin ters } \\
\text { çevrilmesi }\end{array}$ & 1 & Yaşam & 4 \\
\hline Maçın son dakikası & 1 & Yemek & 1 \\
\hline
\end{tabular}

\begin{tabular}{llll} 
Mikser & 1 & Yeni alınmış ayakkabı & 1 \\
Motor & 1 & Yeryüzünü kaplayan kar & 1 \\
Motosiklet & 1 & Yol & 1 \\
Namludan çıkan kurşun & 1 & Zaman & 2 \\
Nar & 1 & Zevk almadan yaşamak & 1 \\
Nasrettin Hoca'nın eşeğe & 1 & & \\
ters binmesi & & \\
\hline Toplam & & 161 \\
\hline
\end{tabular}

Tablo 2'de görüldüğü gibi Türkçe öğretmeni adayları tarafindan hızlı okuma becerisine yönelik 161 adet geçerli metafor üretilmiştir. $\mathrm{Bu}$ metaforlardan bazıları ortak olduğundan çalışma sonucunda ulaşılan farklı metafor sayısı 122 olarak gerçekleşmiştir. Ortak metaforlar içinde en fazla kullanılanlar yarış atı $(\mathrm{f}=6), s u(\mathrm{f}=5)$, araba sürmek $(\mathrm{f}=4)$, at yarlşı $(\mathrm{f}=4)$, hızl yemek yemek $(\mathrm{f}=4)$, rap müzik $(\mathrm{f}=4)$, uçak $(\mathrm{f}=4)$ ve yaşam $(\mathrm{f}=4)$ olmuştur. Bunların dişında hızlı giden $\operatorname{araba}(\mathrm{f}=3), \operatorname{yarlş} \operatorname{arabasl}(\mathrm{f}=3), \operatorname{aşk}(\mathrm{f}=2)$, hizlı tren $(\mathrm{f}=2)$, sağanak yağmur $(\mathrm{f}=2)$, sel $(\mathrm{f}=2)$, rüya $(\mathrm{f}=2)$, şelale $(\mathrm{f}=2)$, yarlş $(\mathrm{f}=2)$ ve zaman $(\mathrm{f}=2)$ metaforları da katılımcılar tarafindan birden fazla üretilen metaforlar olarak öne çıkmıştır.

"Türkçe öğretmeni adaylarının hızlı okuma becerisine yönelik oluşturdukları metaforlar hangi kategoriler altında toplanabilir?" şeklindeki ikinci araştırma sorusuna yönelik bulgular Tablo 3 'te gösterilmiştir.

Tablo 3. Hızlı Okuma Becerisine Yönelik Metaforların Kavramsal Kategorileri

\begin{tabular}{|c|c|c|}
\hline Kavramsal Kategori & $\mathrm{f}$ & $\%$ \\
\hline "Teknik gerektiren" bir eylem olarak hızlı okuma & 30 & 18.63 \\
\hline "Beyhude" bir eylem olarak hızlı okuma & 19 & 11.80 \\
\hline "Kolaylaştırıcı" bir eylem olarak hızlı okuma & 19 & 11.80 \\
\hline "Geliștiren" bir eylem olarak hızlı okuma & 18 & 11.18 \\
\hline $\begin{array}{l}\text { “Güzellikleri görmeyi engelleyen” bir eylem olarak } \\
\text { hızlı okuma }\end{array}$ & 18 & 11.18 \\
\hline "Hata yaptıran" bir eylem olarak hızlı okuma & 13 & 8.07 \\
\hline "Rekabetçi” bir eylem olarak hızlı okuma & 12 & 7.46 \\
\hline "Süreç gerektiren" bir eylem olarak hızlı okuma & 12 & 7.46 \\
\hline "Yorucu" bir eylem olarak hızlı okuma & 11 & 6.83 \\
\hline "Zevk veren" bir eylem olarak hizlı okuma & 9 & 5.59 \\
\hline Toplam & 161 & $\% 100$ \\
\hline
\end{tabular}

Tablo 3 'te görüldüğü gibi Türkçe öğretmeni adaylarının hızlı okuma becerisine yönelik oluşturdukları metaforlar, 10 kavramsal kategori altında toplanmıştır. Bu kategorilerden "Teknik gerektiren bir eylem olarak hizlı okuma" ( $\mathrm{f}=30 ; \%$ 18.63), "Beyhude bir eylem olarak hizlı okuma" ( $\mathrm{f}=19 ; \%$ 11.80), "Kolaylaştırıcı bir eylem olarak hızlı okuma" ( $\mathrm{f}=19$, \% 11.80), "Geliştiren bir eylem olarak hızlı okuma" ( $\mathrm{f}=18$; $\%$ 11.18) ve "Güzellikleri görmeyi engelleyen bir eylem olarak hılı okuma" ( $\mathrm{f}=18 ; \%$ 11.18) en fazla öne çıkan kategoriler olurken "Hata yaptıran bir eylem olarak hızlı okuma" ( $\mathrm{f}=13 ; \%$ 8.07), "Rekabetçi bir eylem olarak hızlı okuma" (f=12; \% 7.46), "Süreç gerektiren bir eylem olarak hızlı okuma" (f=12; \% 7.46), "Yorucu bir eylem olarak hızlı okuma" (f=11;\% 6.83) ve "Zevk veren bir eylem olarak hızlı okuma" ( $\mathrm{f}=9 ; \%$ 5.59) kategorileri de katılımcilar tarafindan oluşturulan metaforlar sonucu ortaya çıkan diğer kavramsal kategoriler olmuştur.

Kavramsal kategoriler arasinda ilk sirada $(\mathrm{f}=30)$ yer alan "Teknik gerektiren bir eylem olarak hızlı okuma" kategorisi içerisindeki metaforlar ve frekansları Tablo 4'te gösterilmiştir. 
Tablo 4. "Teknik Gerektiren Bir Eylem Olarak Hızlı Okuma" Kategorisine Ait Metaforlar

\begin{tabular}{lclc}
\hline Metafor & $\mathrm{f}$ & Metafor & $\mathrm{f}$ \\
\hline Araba sürmek & 2 & Problem çözmek & 1 \\
At başı gitmek & 1 & Saat kurmak & 1 \\
At yarışçıs & 1 & Su & 1 \\
Daktiloda yazı yazmak & 1 & Şalgam içmek & 1 \\
Eyeliner çekmek & 1 & Taramalı tüfek & 1 \\
Filmin özetini izlemek & 1 & Tavşan & 1 \\
Fotoğrafa bakmak & 1 & Telgraf makinesinde hızlı & 1 \\
& & yazı yazmak & \\
Fotoğraf çekmek & 1 & Tespih & 1 \\
Göz & 1 & Trafik lambaları & 1 \\
İlaç & 1 & Uçak & 1 \\
Karınca & 1 & Uzaydan dünyaya bakmak & 1 \\
Keman yayı & 1 & Yapboz & 1 \\
Kum saatinin ters & 1 & Yarış arabası & 1 \\
çevrilmesi & & & \\
Nar & 1 & Yeryüzünü kaplayan kar & 1 \\
Nehir & 1 & Tavşan & 1 \\
\hline Toplam & & & 30 \\
\hline
\end{tabular}

Tablo 4'e göre bu kategori içerisinde Türkçe öğretmeni adaylarının ürettikleri 29 farklı metaforun yer aldığı görülmektedir. $\mathrm{Bu}$ kategorisi içerisinde birden fazla kullanılan tek metafor araba sürmek $(\mathrm{f}=2)$ olmuştur.

Öğretmen adayları tarafindan oluşturulan metaforlardan örnekler aşağıda sunulmuştur:

"Hızlı okuma, araba sürmek gibidir. Çünkü arabayla ne kadar hızlı gidersen yol o kadar çabuk biter. Okumayı da hızl yapmak için öncelikle bu işi nasıl yapman gerektiğini bilmelisin." (4S-10)

"Hızlı okuma, at yarışçısı gibidir. Çünkü hızlı okumada hizlı okuyup anlamak, at yarışında da hizlı olup doğru bir şekilde atın üstünde durmak gerekir.” (3S-35)

"Hızlı okuma, problem çözmek gibidir. Çünkü öncelikle bütünü görmek ve algllamak gerekir. Bütünü görüp algılayınca gerisi çorap söküğ̈̈ gibi gelir.” (3S-4)

"Hızlı okuma, trafik lambaları gibidir. Çünkü ne zaman hazırda beklemen, ne zaman durman ve ne zaman harekete geçmen gerektiğini bilmezsen sonunda okuduğunu anlamazsin." (4S-28)

"Hızlı okuma, yeryüzünü kaplayan kar gibidir. Çünkü her yere örtü gibi serilen kara bakıp onun içindeki ufacık kar tanelerini görmeye benzer. Büyük bir yere baklp aslında detaylara odaklanmak gibi. O detayları seçip bütünü anlamlandirmak gibi." (1S-9)

Çalışmada en çok metafor içeren ( $\mathrm{f}=19)$ kavramsal kategorilerden biri olan "Beyhude bir eylem olarak hızlı okuma" kategorisine ait metaforlara Tablo 5'te yer verilmiştir.
Tablo 5. "Beyhude Bir Eylem Olarak Hizlı Okuma" Kategorisine Ait Metaforlar

\begin{tabular}{lclc}
\hline Metafor & f & Metafor & f \\
\hline Aşk & 2 & Sağanak yağmur & 1 \\
Dünya & 1 & Sel & 1 \\
Hafta sonu & 1 & Serdar Ortaç şarkıları & 1 \\
Hızlı giden araba & 1 & Sicakta içilen 1lık su & 1 \\
Hızlı yemek yemek & 1 & Sunum yapmak & 1 \\
İmgeli şiir & 1 & Tekerleme & 1 \\
Nasrettin Hoca'nın & 1 & Trene bakan öküz & 1 \\
eşeğe ters binmesi & & & \\
Rap müzik & 1 & Yabancı dilde konuşan & 1 \\
& & insanları dinlemek & \\
Road Runner & 1 & Yaşam & 1 \\
\hline Toplam & & & 19 \\
\hline
\end{tabular}

Tablo 5'te görüldüğü gibi bu kategoride 18 farklı metafor yer almaktadır. Bu metaforlardan yalnızca $a s ̧ k(\mathrm{f}=2)$, birden fazla kullanılan metafor olmuştur. Bu kategoriye yönelik olarak öğretmen adayları tarafından oluşturulan metaforlardan örnekler aşağıda yer almaktadır:

"Hızlı okuma, aşk gibidir. Çünkü aşkın da ne başladı̆̆ bellidir ne de bittiği. Geride de bir şey kalmaz. Okuma hızlı olursa kişiye yarar sağlamaz." (4S-30)

"Hızlı okuma, sağanak yağmur gibidir. Çünkü her şeyi bir anda okuruz ama okuduklarimizın etkisi klsa sürede zihnimizden kaybolur." (4S-6)

"Hızlı okuma, sıcakta içilen ılık su gibidir. Çünkü okuyucu, okumaya olan susuzluğunu dindirmek için bir hırsla kitabı okur. Ama sıcakta içilen ılık su gibi susuzluğu dinmez. Kitaptan hiçbir şey anlamaz, bir boşuna içmişlik, okumuşluk olur.” (3S-21)

"Hızlı okuma, yaşam gibidir. İkisi de hızlı ve çabuk biter ama bir şey anlamazsin. Sadece bitirmeye bakarsın." (1S30)

"Kolaylaştırıcı bir eylem olarak hızlı okuma" kavramsal kategorisi altında yer verilen metaforlar $(\mathrm{f}=19)$ Tablo 6'da yer almaktadır.

Tablo 6. "Kolaylaştırıcı Bir Eylem Olarak Hızlı Okuma" Kategorisine Ait Metaforlar

\begin{tabular}{llllll}
\hline Metafor & $\mathrm{f}$ & Metafor & $\mathrm{f}$ & Metafor & $\mathrm{f}$ \\
\hline Çı̆ & 1 & Kum saati & 1 & Yarış & 1 \\
Dă̆ & 1 & Mikser & 1 & Yarış arabası & 1 \\
E-postanın icadı & 1 & Su & 1 & Yarış atı & 2 \\
Işık hızı & 1 & Tatil & 1 & Yemek & 1 \\
İnşaat & 1 & Uçak & 2 & Zaman & 1 \\
Kasırga & 1 & X-ray cihazı & 1 & & \\
\hline Toplam & & & & & 19 \\
\hline
\end{tabular}

Tablo 6'da görüldüğü gibi bu kavramsal kategori altında 17 farklı metafor karşımıza çıkmaktadır. Bunlardan $u c ̧ a k(\mathrm{f}=2)$ ve yarıș atı $(\mathrm{f}=2)$ metaforları katılımcılar tarafindan birden fazla kullanılan metaforlar olmuştur. Öğretmen adaylarının bu metaforlara yönelik oluşturdukları cümlelerden örneklere aşağıda yer verilmiştir:

"Hızlı okuma, çı̆g gibidir. Çünkü kelimeler yı̆̆ılır ve hızlı ilerler. Bu da okuma süresinde bize daha çok zaman kazandirır." (2S-33)

"Hızlı okuma, e-postanin icadı gibidir. Çünkü artık ne o uzun mektuplaşmalar ne de postacılar kalmıştır. İnsanların birbirleriyle yazışması e-postaların çıkışıyla çok daha hızlı 
hâle gelmiştir. Hızlı okuma da bu şekilde hayatımızı kolaylaştırır." (2S-41)

"Hızlı okuma, mikser gibidir. Çünkü mikser bildiğimiz üzere yiyeceklerimizi çok çabuk öğütmeye, doğramaya gerek kalmadan hazır hâle getiren bir şey. Çok çabuk vakit kazandırarak bizi amacımıza ulaştıran bir alet. Hızlı okuma da kelimeleri vakit kaybetmeden hizlı bir şekilde anlamamiza yarlyor. Zaman kazancı. Her şeyi kolay karlştırıp doğramayla, kolay okuyup anlama..." (3S-8)

"Hızlı okuma, uçak gibidir. Çünkü uçak kısa zamanda çok yol alır. Hizlı okuma da öyledir. Kısa zamanda metin üzerinde çok yol alınır." (4S-27)

"Hızlı okuma, yarış atı gibidir. Çünkü hızlı okuma sınav amaçlı yapılan bir eylemdir. Başarı için araçtır. At da jokeyin yarışı kazanması için bir araçtır bence." (1S-18)

"Geliştiren bir eylem olarak hızlı okuma" kategorisi altındaki metaforlara ( $\mathrm{f}=18$ ) yönelik frekans bilgileri Tablo 7'de gösterilmiştir.

Tablo 7. "Geliştirici Bir Eylem Olarak Hızlı Okuma" Kategorisine Ait Metaforlar

\begin{tabular}{llll}
\hline Metafor & f & Metafor & f \\
\hline Alt yazılı film izlemek & 1 & Motor & 1 \\
Araba sürmek & 1 & Rap müzik & 1 \\
Demir & 1 & Ronaldo & 1 \\
Egzersiz & 1 & Saat & 1 \\
Elektrikli süpürge & 1 & Simit oyunu & 1 \\
Gürül gürül akan su & 1 & Spor & 1 \\
Hızlı koşan sporcu & 1 & Şelale & 1 \\
Hızlı tren & 1 & Tarla & 1 \\
Işı & 1 & Tren & 1 \\
\hline Toplam & & & 18 \\
\hline
\end{tabular}

Tablo 7'de görüldüğü gibi bu kategori altındaki bütün metaforlar birbirinden farklıdır. Metaforları örnekleyen katılımcı ifadeleri aşağıda yer almaktadır:

"Hızlı okuma, alt yazılı film izlemek gibidir. Çünkü filmde alt yazılar çok hızlı ilerler, senin de izlediğin filmin saniyesi geçmeden yazıları okuman gerekir. Bu da hız konusunda kişinin kendini eğitmesiyle olur." (1S-31)

"Hızlı okuma, egzersiz gibidir. Çünkü hızlı okuma yaparken beynimizi, gözümüzü çalıştırır, algımızı açık ve zinde tutarı." (2S-6)

"Hızlı okuma, hızlı koşan sporcu gibidir. Çünkü insan okudukça kendini daha ileri götürmek isteyecektir. Hizlı koşan bir sporcu da kendini daha çok geliştirerek hedefini daha yükseğe taşımak ister." (3S-27)

"Hızlı okuma, rap müzik gibidir. Çünkü kısa sürede çok şey anlatır ve anlattıkları da oldukça anlamlıdır. Hızlı okuma, hızlı yapıldiğı için anlaşılmaz sanılsa da kişiye çok şey kazandirır." (4S-4)

Kavramsal kategorilerden bir diğeri olan "Güzellikleri görmeyi engelleyen bir eylem olarak hızlı okuma" kategorisi altındaki metaforlara ( $\mathrm{f}=18$ ) Tablo 8'de yer verilmiştir.
Tablo 8. "Güzellikleri Görmeyi Engelleyen Bir Eylem Olarak Hızlı Okuma" Kategorisine Ait Metaforlar

\begin{tabular}{llll}
\hline Metafor & f & Metafor & f \\
\hline Boşa verilen emek & 1 & Oksijen & 1 \\
Hayal kuramayan sıradan insan & 1 & Öğrenci & 1 \\
Hızlandırılmış ses kaydı & 1 & Roket & 1 \\
Hızlı giden araba & 2 & Rüya & 2 \\
Hızlı tren & 1 & Soğuk balkonda & 1 \\
& & sigara içmek & \\
Hızlı yemek yemek & 2 & Tuzsuz yemek & 1 \\
Kaplumbağa & 1 & Tünel & 1 \\
Kaynar çayı tek nefeste içmek & 1 & & \\
\hline Toplam & & & 18 \\
\hline
\end{tabular}

Tablo 8'e göre bu kategori altında 15 farklı metafor karşımıza çıkmaktadır. Bunlardan birden fazla kullanılanlar ise hızl giden araba $(\mathrm{f}=2)$, hizl l yemek yemek $(\mathrm{f}=2)$ ve rüya $(\mathrm{f}=2)$ 'dır. İlgili metaforları açıklayan örnek cümleler şu şekildedir:

"Hızlı okuma, hızlı giden araba gibidir. Çünkü geçtiği yollarl bir anda görüyor. O araba, o yollardan sadece geçmiş olur. Geçtiği yolların güzelliklerini tam göremez. Hızlı okuma da böyledir. Hizlıca okuyup düşünmeden geçersin ve belki de okuduğun metnin içindeki güzellikleri görüp farkına varamazsin." (1S-29)

"Hızlı okuma, kaynar çayı tek nefeste içmek gibidir. Çünkü çayı içmişsindir ama ă̆zın yanar. İçin ısınır belki ama zevk alamazsın, çayın tadına varamazsın." (2S-1)

"Hizlı okuma, roket gibidir. Çünkü okuduğundan bir şey anlamazsın. Roket de hızından dolayı gökyüzünün farkında değildir." (1S-7)

"Hızlı okuma, tuzsuz yemek gibidir. Çünkü o yemeği yediğinde doyarsın ama zevk alamazsın. Hizlı okuduğunda da anlarsın ama üstünde düșünemediğinden güzel gelmez." (1S-36)

"Hata yaptıran bir eylem olarak hizlı okuma" kategorisi altında toplanan metaforlara $(\mathrm{f}=13)$ yönelik bilgiler Tablo 9'da yer almaktadir.

Tablo 9. "Hata Yaptıran Bir Eylem Olarak Hizlı Okuma" Kategorisine Ait Metaforlar

\begin{tabular}{lclc}
\hline Metafor & $\mathrm{f}$ & Metafor & $\mathrm{f}$ \\
\hline Acele yapılan iş & 1 & Parkur koşmak & 1 \\
Araba sürmek & 1 & Trafik kazası & 1 \\
Araba yarışı & 1 & Volkan Demirel & 1 \\
At yarışı & 1 & Yanlış yola girmiş araba & 1 \\
Maçın son dakikası & 1 & Yaşam & 1 \\
Namludan çıkan kurşun & 1 & Zaman & 1 \\
Otobüse yetişmek & 1 & & 13 \\
\hline Toplam & & & \\
\hline
\end{tabular}

Tablo 9'da görüldüğü üzere bu kavramsal kategoriye dâhil metaforların hepsi birbirinden farklıdır. Katılımcılar tarafindan bu metaforlar için oluşturulan cümlelerden örnekler aşağıda yer almaktadır:

"Hızlı okuma, araba sürmek gibidir. Çünkü ilerleme kat edersin ama bunun yaninda kural ihlali de yaparsin." (1S42)

"Hızlı okuma, maçın son dakikası gibidir. Çünkü hızlı okuduğumuzda bir telaşa kapılırız. Aynı şekilde maçta yenilen takım da telaşlanır." (1S-25) 
"Hızlı okuma, trafik kazası gibidir. Çünkü bir anda olur biter. Bu sebeple okuma eylemi dikkatli yapılmalıdır. Aksi takdirde kötü sonuçlarla karşılaşılabilir.” (4S-16)

"Hızlı okuma, yanlış yola girmiş araba gibidir. Çünkü bir araba yanlış yola girdiyse dikkatsizlikten dolayıdır. Hızl okumada da dikkatimiz dağılabilir." (3S-14)

"Rekabetçi bir eylem olarak hızlı okuma" kategorisinde yer alan metaforlara $(\mathrm{f}=12)$ yönelik bilgilere Tablo 10'da yer verilmiştir.

Tablo 10. "Rekabetçi Bir Eylem Olarak Hızlı Okuma" Kategorisine Ait Metaforlar

\begin{tabular}{lllllr}
\hline Metafor & f & Metafor & f & Metafor & f \\
\hline Atletizm & 1 & Çita & 1 & Yarış & 1 \\
At yarış1 & 3 & Depar atmak & 1 & Yarış atı & 2 \\
Çakal & 1 & Son dakika golü & 1 & Yol & 1 \\
\hline Toplam & & & & 12 \\
\hline
\end{tabular}

Tablo 10'a göre bu kategori içerisinde 9 farklı metafor olduğu görülmektedir. Bunlardan at yarışı $(\mathrm{f}=3)$ ile yarış at $(\mathrm{f}=2)$ katılımcilar tarafindan birden fazla tercih edilen metaforlardır. Öğretmen adaylarının tablodaki metaforlara yönelik oluşturdukları ifadelerden bazıları şu şekildedir:

\footnotetext{
"Hızlı okuma, at yarışı gibidir. Çünkü jokeyi birinciliğe koşar. Her iki olayda da hız ön plandadır. Ama daha hızlı olan kazanir." (3S-29)

"Hızlı okuma, çita gibidir. Çünkü çita, dünyadaki diğer hayvanlara göre çok kısa zamanda çok daha hızlı koşarak daha fazla yol alabilir. Insanlar da hizlı okumayla normal okumaya göre çok kısa zamanda daha fazla kelime ve daha uzun bir metin okuyabilir." (3S-15)

"Hizlı okuma, yarış gibidir. Çünkü hızlı okuduğunda herkesten bir adım önde olursun." (4S-3)

"Hızlı okuma, yol gibidir. Çünkü ne kadar hılı okursan o kadar çok yol kat edersin. Bu da seni diğer kişilerin önüne geçirir." (1S-46)
}

Kavramsal kategorilerden "Süreç gerektiren bir eylem olarak hızlı okuma"ya yönelik metaforlar $(\mathrm{f}=12)$ Tablo 11'de yer almaktadır.

Tablo 11. "Süreç Gerektiren Bir Eylem Olarak Hızlı Okuma" Kategorisine Ait Metaforlar

\begin{tabular}{lllr}
\hline Metafor & f & Metafor & f \\
\hline Acı biber & 1 & Rap müzik & 1 \\
Arı & 1 & Sağanak yağmur & 1 \\
Bisiklet sürmek & 1 & Timsah & 1 \\
Ekşi yüz & 1 & Yarış atı & 1 \\
Hızlı yaşamak & 1 & Yaşam & 1 \\
İnsanları tanımak & 1 & Yeni alınmış ayakkabı & 1 \\
\hline Toplam & & & 12 \\
\hline
\end{tabular}

Tablo 11 'e göre bu kavramsal kategori altındaki metaforların da birbirinden farklı olduğu görülmektedir. Metaforlara yönelik katılımcıların kurdukları cümlelerden örneklere aşağıda yer verilmiştir:

"Hızlı okuma, acı biber gibidir. Çünkü acı biberi yediğimiz ilk anlarda acı olup olmadığını fark edemeyiz. Sonradan acısı çıkar. Hızlı okumada önce hızlıca okuyup hemen anlamamız zor olur, anlamlandırma becerisi daha geç kazanilır." (3S-9)

"Hızlı okuma, rap müzik gibidir. Çünkü hızlı okuma yeri geldiğinde hizlı olduğu kadar, ilk okumada anlaşılamayabiliyor. Rap müzik de ilk duyulduğunda anlaşılmasa da sonraki dinleme aşamasında anlaşılabiliyor." (4S-19)

"Hızlı okuma, yarış atı gibidir. Çünkü ondan belli bir süre içinde üstün bir performans beklenir. Nastl ki bir yarış atı belli bir süreden sonra belli bir hıza ve çevikliğe ulaşır, hızlı okuma da belli bir eğitim sonucu elde edilir." (3S-17)

"Hızlı okuma, yeni alınmış ayakkabı gibidir. Çünkü ayakkabı da yol aldıkça açılır." (2S-44)

"Yorucu bir eylem olarak hızlı okuma" kategorisi altında yer alan metaforlara yönelik bilgiler Tablo 12'de gösterilmiştir.

Tablo 12. "Yorucu Bir Eylem Olarak Hizlı Okuma" Kategorisine Ait Metaforlar

\begin{tabular}{llll}
\hline Metafor & f & Metafor & f \\
\hline Atanamamış öğretmen & 1 & Rap müzik & 1 \\
Doğan (araba) & 1 & Sel & 1 \\
Et makinesi & 1 & Yarış arabası & 1 \\
Hızlı koşan at & 1 & Yarı̧ atı & 1 \\
Hızlı yemek yemek & 1 & Zevk almadan yaşamak & 1 \\
Kalemin tahtada çıkardı̆̆ı ses & 1 & & \\
\hline Toplam & & & 11 \\
\hline
\end{tabular}

Tablo 12'ye göre bu kategori altındaki metaforlar birbirinden farklıdır. Katılımcıların ilgili metaforlara yönelik açıklamalarından örnekler aşağıdadır:

"Hızlı okuma, atanamamışögretmen gibidir. Çünkü çok yol kat edersin, az şey başarırsin." (2S-19)

"Hızlı okuma, doğan (araba) gibidir. Çünkü doğanda birden gaza basarsin, gazın çabuk biter. Hizlı okumada da çok çabuk okursun, nefesin biter.” (2S-8)

"Hızlı okuma, sel gibidir. Çünkü su hızlı akttğı için insanı rahatsiz eder. Hizlı okuma da böyledir. Insana bir huzursuzluk, rahatsizllk verir. Insana okuma zevki vermez." (1S-8)

"Hızlı okuma, yarış atı gibidir. Çünkü atlar da koşmayı severler ama belli bir hıza ulaștıktan sonra yorulurlar. Hızlı okuma da böyledir. İlk başta eğlenceli gelir ama bir süre sonra gözlerimiz yorulur." (4S-24)

Kavramsal kategorilerin sonuncusu olan "Zevk veren bir eylem olarak hızlı okuma" kategorisinde yer alan metaforlar (f=9) Tablo 13'te yer almaktadir.

Tablo 13. "Zevk Veren Bir Eylem Olarak Hizlı Okuma" Kategorisine Ait Metaforlar

\begin{tabular}{llllll}
\hline Metafor & f & Metafor & f & Metafor & f \\
\hline Çikolata & 1 & Su & 3 & Uçak & 1 \\
Eti Tutku & 1 & Şelale & 1 & Yaşam & 1 \\
Motosiklet & 1 & & & & \\
\hline Toplam & & & & & 9 \\
\hline
\end{tabular}

Tablo 13'te görüldüğü gibi 7 farklı metafor bu kategori altında toplanmıştır. Birden fazla kullanılan tek metafor ise $s u(\mathrm{f}=3)$ metaforu olmuştur.

"Hızlı okuma, çikolata gibidir. Çünkü hemen bittiği için tadina varamayız." (4S-8)

"Hızlı okuma, su gibidir. Çünkü su akıp gider, tıpkı hızlı okumadaki kelimeler gibi. Kelimelerin hızlı akışı okuyana huzur verir." (4S-14)

"Hızlı okuma, uçak gibidir. Çünkü herhangi bir mesafeyi araba, otobüs vs. ile gidersek daha çok vakit harcarız fakat uçak ile hem kısa sürede hem de daha eğlenceli şekilde gidebiliriz." (2S-40) 
"Hızlı okuma, yaşam gibidir. Çünkü öylesine güzeldir ki göz açıp kapayıncaya kadar biter." (1S-37)

Araştırmanın üçüncü sorusu olan “Türkçe öğretmeni adayları tarafindan oluşturulan metaforlar sonucu ortaya çıkan kavramsal kategorilerin olumluluk-olumsuzluk özelliklerine göre dağılımı nasıldır?" sorusuna yönelik dağılım Grafik 1'de gösterilmiştir.

Grafik 1. Kavramsal Kategorilerin Olumluluk-Olumsuzluk Özelliğine Göre Dağılımı

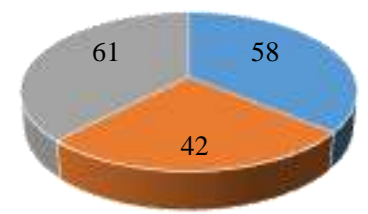

- Olumlu metaforlar

- Şartl1-olumlu metaforlar

- Olumsuz metaforlar

Grafik 1'de görüldüğü gibi araştırma sonucu ortaya çıkan kavramsal kategorilerdeki metaforlar olumlu, şartlı-olumlu, olumsuz olmak üzere üç başlıkta ele alınmıştır. "Kolaylaştırıcı bir eylem olarak hızlı okuma" (f=19), "Geliştiren bir eylem olarak hızlı okuma" (f=18), "Rekabetçi bir eylem olarak hızlı okuma" $(\mathrm{f}=12)$ ve "Zevk veren bir eylem olarak hızlı okuma" (f=9) kategorilerindeki metaforlar olumlu metaforlar ( $\mathrm{f}=58, \% 36)$; "Teknik gerektiren bir eylem olarak hızlı okuma" (f=30) ile "Süreç gerektiren bir eylem olarak hizlı okuma" $(\mathrm{f}=12)$ kategorilerindeki metaforlar şartl1-olumlu metaforlar $(\mathrm{f}=42 ; \%$ 26); "Beyhude bir eylem olarak hızlı okuma" (f=19), "Güzellikleri görmeyi engelleyen bir eylem olarak hizlı okuma" (f=18), "Hata yaptıran bir eylem olarak hizlı okuma" (f=13) ve "Yorucu bir eylem olarak hizlı okuma" (f=11) kategorilerindeki metaforlar da olumsuz metaforlar ( $\mathrm{f}=61 ; \% 38)$ başlığ altında ele alınmıştır. Olumlu, şartlı-olumlu ve olumsuz metaforların sınıf seviyelerine göre dağılımına ilişkin sayısal veriler Grafik 2'de gösterilmiştir.

Grafik 2. Olumlu, Şartlı-Olumlu, Olumsuz Kategorilerin Sınıflara Göre Dağ 11 เıı

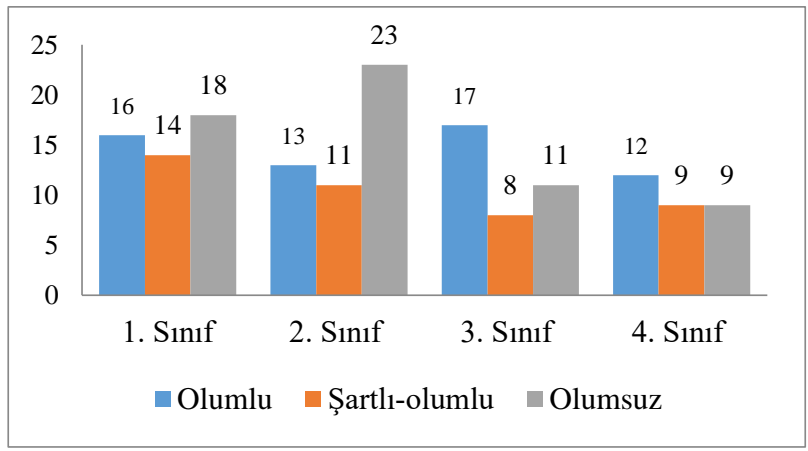

Grafik 2'ye göre 1. sınıf öğrencileri tarafından oluşturulan ( $\mathrm{f}=48)$ metaforların 16'sı olumlu (\% 33), 14'ü şartlı olumlu (\% 29) ve 18'i de olumsuz (\% 38) özellik taşımaktadır. 2. sınıf öğrencileri ( $\mathrm{f}=47)$ tarafindan oluşturulan metaforların 13'ü olumlu (\% 28), 11'i şartlı olumlu (\% 23), 23'ü ise olumsuz (\% 49) özelliktedir. 3. sinıf öğrencilerinin ( $\mathrm{f}=36)$ oluşturduğu metaforların 17'si olumlu (\% 47), 8'i şartl1olumlu (\% 22), 11'i ise olumsuz (\% 31) metaforlardır. 4. sınıf öğrencileri $(\mathrm{f}=30)$ tarafindan oluşturulan metaforlar ise 12'si olumlu (\% 40), 9'u şartl1-olumlu (\% 30) ve 9'u da olumsuz (\% 30) metaforlar şeklinde siralanmaktadır. Bu sonuca göre 1. ve 2. sınıf öğrencilerinin hızlı okuma becerisine yönelik algıları daha çok olumsuz düzeydeyken 3 . ve 4. sınıf öğrencilerinde bu durum olumlu yönde seyretmektedir.

\section{Sonuç, Tartışma ve Öneriler}

Bilgi edinmenin önemli bir yolu olan okuma becerisi, bilgi kaynaklarının her geçen gün artmasıyla daha da önemli hâle gelmektedir. Günümüzde daha çok bilgiye ulaşmak, daha çok ve daha hızlı okumakla mümkün olduğundan okuma hızının artırılması, bireylerin günlük hayatlarını kolaylaştıracak, onların okumaya ayırdıkları zamandan tasarruf etmelerini ve var olan zamanı daha etkili kullanmalarını sağlayacaktır. Her beceride olduğu gibi, hızlı okuma becerisinde de bireylerin bakış açıları ve algıları onların ilgili beceriye olumlu veya olumsuz tutum takınmalarında etkili olacaktır. Öğrencilere okuma/hızlı okuma konusunda rehberlik yapacak olan öğretmenlerin öncelikle bu becerilerde kendilerinin yetkin olması bu noktada önem kazanmaktadır. Bu çalışmada geleceğin Türkçe öğretmenlerinin hızlı okuma becerisine yönelik algılarını metaforlar yoluyla tespit etmek amaçlanmıştır.

Türkçe öğretmeni adayları tarafindan oluşturulan 161 geçerli metafordan bazıları birden fazla katılımc1 tarafindan oluşturulmuş, böylece araştırma sonunda ortaya 122 farklı metafor çıkmıştır. Oluşturulan metafor sayısının fazla olmasında ögrretmen adaylarının hızlı okuma becerisini geniş bir açıdan ele almış olmalarının ve beceriyi çok boyutlu bir şekilde düşünmelerinin etkisi olabileceği söylenebilir. Elde edilen metaforlardan birden fazla katılımcı tarafından tercih edilenler içinde yer alan yarış atı, su, araba sürmek, at yarışl, hızlı yemek yemek, rap müzik, uçak, yaşam, hızlı giden araba ve yarış arabası, bu ortak metaforlar içerisinde en çok kullanılanlardır. Ortak metaforların geneline baktığımızda öğretmen adaylarının hızlı okuma becerisini "hareket" kavramıyla birlikte düşündükleri şeklinde bir yorum yapılabilir. Bu konuda yapılabilecek bir diğer yorum ise katılımcıların hızlı okuma becerisine yönelik algılarında "ulaşım" unsurunun ön planda olduğudur. At, araba, yarış arabası, uçak gibi ulaşım araçlarının öğretmen adayları tarafından çokça tercih edilmesi, hızlı okumanın -tıpkı ulaşım araçlarında olduğu gibi- bireyi hedefe ulaştırmadaki önemini vurgulaması bakımından dikkate değerdir. Ulusoy (2013) tarafından yapılan ve sınıf öğretmeni adaylarının öğrenme alanlarına dair algılarını metaforlar yoluyla tespit etmeyi amaçlayan çalışmada da okuma becerisi için oluşturulan kategorilerden biri "Ulaşım aracı" ( $\mathrm{f}=22, \%$ 10.89) olarak ortaya çıkmıştır. Buna göre benzetmelerde ulaşım araçlarının özelliklerinden yararlanarak metafor üretme düşüncesi hem okuma hem de hılı okuma becerisinde karşımıza çıkmaktadır. Okuma becerisi bireyin bilgiye ulaşabileceği en önemli yollardan biri olduğu için katılımcıların bu sebeple beceriyi tanımlarken ulaşım araçlarına vurgu yapmış oldukları düşünülebilir.

Katılımcılar tarafından oluşturulan metaforlar sonucu ortaya çıkan kavramsal kategoriler 10 maddede ele alınmış, bu kategorilerden "Teknik gerektiren bir eylem olarak hızlı okuma", belirgin bir farkla ilk sırada yer almıştır. Bu durum, öğretmen adaylarının hızlı okuma becerisinin önemine inandıkları, ancak belirli tekniklerin bilindiği/uygulandığı 
takdirde hızlı okumanın bireye istenen faydayı sağlayacağını düşündükleri şeklinde açıklanabilir. Nitekim alan yazında hızlı okuma teknikleri eğitiminin, çeşitli öğrenim kademelerindeki öğrencilerin okuma hızlarına ve anlama düzeylerine olumlu etkilerinin olduğunu ortaya çıkaran çalışmalar mevcuttur (Bozan, 2012; Dedebali, 2008; Kaçar, 2015; Soysal, 2015; Yalçın, Erdoğan-Çeltik ve Altınok, 2017). Buna karşın bahsi geçen tekniklerin bireysel özelliklere bağlı olarak her kişide farklı düzeyde bir gelişim sağlayabileceği, hatta aynı kişinin farklı metinleri okurken bile farklı hız ve anlama düzeyleri ile okuyabileceği de göz önünde bulundurulmalıdır (Coşkun, 2002). Öğretmen adaylarının hızlı okumanın istenen verimi sağlayabilmesinde bir diğer dikkat çektikleri konu, bu becerinin süreç içerisinde gelişebilecek/geliştirilebilecek bir beceri olduğunu kabul etmektir. Bu düşüncede olan katılımcıların oluşturdukları metaforlar ( $\mathrm{f}=12)$ "Süreç gerektiren bir eylem olarak hızlı okuma" kavramsal kategorisi altında toplanmıştır. Gündüz ve Şimşek'e (2011) göre alışkanlıklar değiştirilmesi zor davranışlardır. Bunlar zamanla ve yapılacak tekrarlar sonucu geliştirilebilir. Ancak kararlı ve sabırlı olmak koşuluyla sahip olunan alışkanlıklardan vazgeçmek ve sahip olunacak davranışları tekrarlamak suretiyle yeni alışkanlıklar edinilebilir. Bütün bunların ise belli bir sürece yayılması zorunludur. Hızlı okumayı teknik ve süreç gerektiren bir beceri olarak değerlendiren öğretmen adaylarının metaforları, hızlı okumaya karşı oluşturulan şartlı-olumlu metaforlar ( $\mathrm{f}=42, \%$ 26) başlığ $\breve{g}_{1}$ altında toplanmıştır. Zira gerekli olan bu şartlar sağlan(a)madığı müddetçe, hızlı okuma becerisi hem istenen düzeyde olmayacak hem de bu beceriyi kullanan kişiye fayda sağlamayacaktır. Bozpolat (2015) tarafından Türkçe öğretmeni adaylarının dört temel dil becerisine yönelik metafor algılarını tespit etmeye dönük gerçekleştirilen çalışmada katılımcıların okuma becerisi için oluşturdukları metaforlar neticesinde ortaya çıkan "Parçaların birleştirilmesi olarak okuma" (f=3) kategorisi bu araştırmanın "Teknik gerektiren bir eylem olarak hızlı okuma"; "Sistemli bir süreç olarak okuma" (f=1) kategorisi ise "Süreç gerektiren bir eylem olarak hızlı okuma" şeklindeki şartli-olumlu kategorileriyle benzer görülmektedir. Yine Ulusoy’un (2013) araştırmasında okuma becerisi için ortaya konulan kavramsal kategorilerden "Parça-Bütün"ü ( $\mathrm{f}=11)$, "Teknik gerektiren bir eylem olarak hızlı okuma"; "Süreklilik"i ( $\mathrm{f}=6)$ ise "Süreç gerektiren bir eylem olarak hızlı okuma" kavramsal kategorileriyle benzer düşünebiliriz. Benzetmelerdeki süreç vurgusu okuma/hızlı okuma becerisinin kazanılmasinda ve devam ettirilmesinde sabırlı davranılması gerektiğini, kısa süre içerisinde bu becerilerde yetkin olunamayacağını göstermektedir.

Öğretmen adaylarının hızlı okumaya yönelik algılarında olumsuz düşüncelerinin de yerinin olduğunu söylemek mümkündür. Katılımcılar arasında hizlı okumanın "beyhude" "güzellikleri görmeyen engelleyen", "hata yaptıran" ve "yorucu" bir eylem olduğuna inananların oranı \% 38 ( $\mathrm{f}=61)$ olarak belirlenmiş, bu kavramsal kategoriler altında yer alan metaforlar "olumsuz metaforlar" başlığı altında toplanmıştır. Azizoğlu ve Okur (2018) tarafından 1. ve 4. sınıfta öğrenim gören 59 Türkçe öğretmeni adayı ile gerçekleştirilen ve onların ekran okumaya yönelik algılarını belirlemeyi amaçlayan araştırmada 1. sınıf Türkçe öğretmeni adayları arasından altı kişi, son sınıf Türkçe öğretmeni adayları arasından ise bir kişi hariç diğerlerinin ekrandan okuma kavramına ilișkin olumsuz tanımlama ve açıklamalarda bulundukları sonucuna ulaşılmıștır. Araştırmada ekran okumayı "zor olarak görme”, "değersiz görme" gibi doğrudan olumsuzluk çağrıştıran kavramsal kategorilerin oluşturulduğu da görülmektedir. Lüle-Mert'in (2013) Türkçe öğretmeni adaylarının temel dil becerilerine yönelik algılarını incelediği araştırmada, katılımcıların okuma becerisine yönelik "Bilinmezlik" ( $\mathrm{f}=4)$, "Zor ve sıkıcı bir eylem olarak okuma" ( $\mathrm{f}=3)$, "Zorunlu bir eylem olarak okuma" ( $\mathrm{f}=3$ ), "Karmaşık bir eylem olarak okuma" ( $\mathrm{f}=1$ ) gibi olumsuz metaforlar ürettikleri görülmüştür. Ancak ilgili araştırmada katılımcıların okuma becerisine yönelik algılarının büyük bir oranda olumlu yönde olduğu tespit edilmiştir. Okuma becerisiyle ilgili olumlu düşüncelerin ağırlıkta olduğu bir diğer çalışma Karakuş ve Kozçetin'e (2016) aittir. Bu çalışmada da Türkçe öğretmeni adaylarının okuma becerisine yönelik oluşturdukları tek olumsuz kategori "Bunaltıcı" başlığıyla ele alınmış, bu kategori \% 2 . 68 ile çok düşük bir düzeyde kalmıştır. Calp'e (2010) göre toplumda hızlı okumanın, anlamadan yapılan bir okuma şekli olduğu düşüncesinin yerleşmiş olmasından dolayı hızlı okuma denilince dinleyenlerde şüphe ve tereddütler oluşmaktadır. Buna ise bir metni normalden daha hızlı okuduğumuz takdirde okuduğumuzu anlamakta güçlük çekeriz endişesi neden olmaktadır. Çalışmada hızlı okumaya yönelik olumsuz düşüncelerin fazla olmasında toplumda var olan bu düşüncelerin etkisinin olabileceği tahmin edilmektedir. Yine bu olumsuz düşüncelerin ortaya çıkmasında hızlı okuma becerisinin tam olarak ne olduğunun bilinmemesi, kısacası becerinin yeterince tanınmaması, bunun neticesinde beceriye karşı ön yargılı olunması gibi faktörlerin de etkili olabileceği düşünülmektedir.

Hızlı okuma becerisini herhangi bir şarta bağlı kalmadan olumlu özellikleriyle ele alan katılımcılar, hızlı okumaya olumsuz açıdan bakanlarla oran olarak çok yakındır. Hızlı okuma algıları olumlu yönde olan öğretmen adayları, bu becerinin kişinin hayatını kolaylaştırıcı yönüne vurgu yapmış, bu beceriyi kullananların kendini geliştirebileceğini ve bu gelişim sayesinde diğer insanlarla rekabet edebileceğini belirtmiştir. Bu beceriye dönük algısı olumlu yönde olan bazı katılımcılar da hızlı okumanın, onu hayatında uygulayanlara zevk veren yönüne değinmişlerdir. Burada ortaya çıkan olumlu kategorilere benzer sonuçlara başka araştırmalarda da rastlanmaktadır. Susar-Kırmızı ve Çelik (2015) tarafından ilkokul 2. sınıf öğrencileriyle yapılan araştırmada ilk okuma yazma süreci için ortaya çıkan "Eğlence" (\% 39. 78); Köksal, Erginer ve Baloğlu (2016) tarafından ilkokul 1. sınıf öğrencileriyle yapılan çalışmada okuma yazma becerisi için oluşturulan "Eğlendiricilik" (\% 14,3); Karakuş ve Kozçetin (2016) tarafından yapılan araştırmada okuma becerisine yönelik geliştirilen "Rahatlatıcı" (\% 12.08) kategorileri bu araştırmanın "Zevk veren bir eylem olarak hizlı okuma" kategorisiyle benzerdir. Susar-Kırmızı ve Çelik'in (2015) araştırmasında ilk okuma yazma süreci için karşımıza çıkan "Gelişim" (\% 15.21) kategorisi ile Karakuş ve Kozçetin'in (2016) araştırmasında okuma becerisi için oluşturulan "Gelişme-genişleme" (\% 13.89) kategorileri de "Rekabetçi bir eylem olarak hızlı okuma" kategorisine benzer özelliktedir.

Hızlı okuma becerisine yönelik olarak geliştirilen metaforların olumluluk-olumsuzluk dağılımı sınıflar düzeyinde farklılık göstermektedir. 1. ve 2. sınıf öğrencileri hızlı okuma becerisine karşı daha olumsuz bir tutum sergilerken 3 . ve 4 . sınıf öğrencilerinde becerinin daha 
olumlu algılandığı ifade edilebilir. Ayrıca 3. sınıf öğrencilerinin, 4. sınıf öğrencilerine; 1. sınıf öğrencilerinin de 2. sınıf öğrencilerine göre hızlı okuma becerisi konusuna daha olumlu baktıkları söylenebilir. Bu sonucun ortaya çıkmasında, özellikle başta "Anlama ve Anlatma Teknikleri" şeklinde karşımıza çıkan alan bilgisi derslerinin (Okuma Eğitimi, Dinleme Eğitimi, Konuşma Eğitimi, Yazma Eğitimi) 3. sınıf programında yer alıyor olmasının etkili olabileceği düşünülmektedir. Yine son sınıflardaki öğretmen adaylarının, üniversite geçmişlerinin ilk sınıflardakilere nazaran daha eski olması, öğrenimleri süresince bu beceriye daha fazla ihtiyaç duymalarını sağlayacağından hızlı okuma konusunda kendilerini geliştirmiş olabilecekleri de söylenebilir. Okuma becerisi üzerine yapılan ve sinıf düzeylerinin değişken olarak dikkate alındığ 1 farklı çalışmaların farklı sonuçlar ortaya çıkardığ görülmektedir. Batur, Gülveren ve Bek (2010) tarafindan öğretmen adayları üzerinde yapılan araştırmada okuma alışkanlığına yönelik en olumlu tutuma 3. sinif, en olumsuz tutuma ise 1. sinif öğrencilerinin sahip olduğu belirlenmiştir. Biçer ve Alan'ın (2017) Türkçe öğretmeni adaylarının kitap okuma alışkanlığı tutumlarına yönelik çalışmasında istatistiksel olarak anlamlı fark olmasa da en yüksek ortalamanın 3. sınıf, en düşük ortalamanın 2. sınıf öğrencilerinde olduğu tespit edilmiştir. Karakuş ve Baki'nin (2014) Türkçe öğretmeni adaylarının kitap okuma alışkanlıklarını inceledikleri çalışmada sınıflar arasında anlamlı bir fark olmamakla birlikte en yüksek ortalamanın 2. sınıf düzeyindeki öğrencilere ait olduğu ortaya çıkmıştır. Koçak, Çermik, Polat ve Şahin (2016) tarafından öğretmen adayları üzerinde yapılan bir diğer araştırmada ise kitap okumaya yönelik tutum puanının en yüksek olduğu sınıf 1 , en düşük olduğu sınıf 4. sınıf olmuştur. Kurudayığlu ve Çelik (2013) tarafından Türkçe öğretmenliği 3. ve 4. sınıf öğrencileriyle gerçekleştirilen çalışmada, 4. sınıfta okuyan öğretmen adaylarının okuma eğitimi konusundaki yeterlilik düzeylerine ilişkin tutumlarının, 3. sınıfa devam eden öğretmen adaylarının tutumlarına göre daha olumlu olduğu görülmüştür.

Sonuç olarak öğretmen adaylarının hızlı okuma becerisine yönelik ürettikleri metaforların olumluluk-olumsuzluk oranlarının birbirine yakın olduğunu söylemek mümkündür. Bunun yanında öğretmen adaylarının belirli bir bölümü ise hızlı okumanın, belirli şartların gerçekleşmesi neticesinde bireye olumlu katkı sunacağını düşünmektedir.

Elde edilen sonuçlardan hareketle hızlı okuma konusunda yapılabilecek çalışmalar için şu öneriler sunulmuştur:

Türkçe öğretmeni adayları, temel dil becerilerini içeren derslerle akademik hayatlarında daha sık karşılaştıklarından, öğretmen yetiştiren diğer programlardaki öğrencilerle yapılacak bu türden çalışmalar, programlar arasında karşılaştırma yapma imkânı da sunacaktır.

Katılımcıların hızlı okuma becerisine yönelik olumsuz algıları, duyuşsal özelliklerin belirlenmesini gerekli kılmaktadır. Bu noktada öğretmen adaylarının hızlı okuma konusundaki algıları, tutumları, kaygıları, görüşleri gibi birçok faktör geliştirilecek/uygulanacak olan ölçek, anket, görüşme soruları vb. ile belirlenmelidir. Böylece bu beceriye yönelik olan olumsuz düşüncelerin sebepleri tespit edilip çözüm yolunda öneriler getirilmeli ve bu konuda çalışmalar yapilmalidir.
Hızlı okuma teknikleri konusunda gerek MEB'e bağlı ilkokul, ortaokul ve liselerde, gerekse üniversitelerde seçmeli dersler açılıp öğrencilerin bu beceriyle tanışması sağlanmalıdır. Yine hızlı okuma-anlama becerisini ölçen çalışmalarla öğrencilerin ilgisi ve dikkati bu beceriye çekilmelidir.

Öğrencilerin hızlı okuma becerisine yönelik bilgi sahibi olabilmesi, var olan olumsuz düşüncelerin ortadan kaldırılması adına konunun uzmanlarıyla gerçekleştirilecek panel, konferans, söyleşi türü etkinliklere zaman ayrılmalı, öğrenciler hızlı okumanın günlük hayattaki işlevselliği noktasında bilgilendirilmelidir.

\section{Kaynakça}

Akkaya, A. (2011). İlköğretim 8. sinıf öğrencilerinin konuşma kavramına ilişkin algıları. Adıyaman Üniversitesi Sosyal Bilimler Enstitüsü Dergisi, 4(7), 1-9.

Akturan, U., \& Esen, A. (2008). Fenomenoloji. Türker Baş ve Ulun Akturan (Ed.), Nitel araştırma yöntemleri içinde (ss. 83-98). Ankara: Seçkin Yayıncılık.

Akyol, H. (2006). Türkçe öğretim yöntemleri. Ankara: Kök Yayınc1lık.

Arat, M., \& Turgut, T. (2011). F1 hızlı okuma. İstanbul: Nesil Yayınları.

Arıcı, A. F. (2012). Okuma eğitimi. Ankara: Pegem Yayınlar1.

Arslan, M. M., \& Bayrakçı, M. (2006). Metaforik düşünme ve öğrenme yaklaşımının eğitim öğretim açısından incelenmesi. Millî Ĕ̈itim Dergisi, 171, 100-108.

Aydeş, S. S., \& Akın, U. (2016). Okul yöneticilerinin öğretmenlere yönelik metaforik alg1lar1. Sakarya Üniversitesi Eğitim Bilimleri Enstitüsü Dergisi, 6(3), 2039.

Aydın, F. (2011). Üniversite öğrencilerinin "çevre" kavramına ilişkin metaforik algıları. Doğu Coğrafya Dergisi, 26, 25-44.

Aykaç, N., \& Çelik, Ö. (2014). Öğretmenlerin ve öğretmen adaylarının eğitim programına ilişkin metaforik algılarının karşılaștırılması. Eğitim ve Bilim, 39(173), 328-340.

Azizoğlu, N. İ., \& Okur, A. (2018). Türkçe öğretmeni adaylarının ekrandan okumaya yönelik metaforik algıları. Mehmet Akif Ersoy Üniversitesi Eğitim Fakültesi Dergisi, 46, 1-21.

Baki, Y., \& Karakuş, N. (2017). Öğretmen adaylarının yazmaya ilişkin algıları ve yazma sürecinde karşılaştıkları güçlükler: RTEÜ örneği. Ahi Evran Üniversitesi Kırşehir Eğitim Fakültesi Dergisi, 18(1), 573-593.

Başaran, M. (2014). 4. sınıf seviyesinde ekrandan ve kâğıttan okumanın okuduğunu anlama, okuma hızı ve metne karşı geliştirilen tutum üzerindeki etkisi. Uşak Üniversitesi Sosyal Bilimler Dergisi, 7(2), 248-268.

Batur, Z., Gülveren, H., \& Bek, H. (2010). Öğretmen adaylarının okuma alışkanlıkları üzerine bir araştırma: 
Uşak Eğitim Fakültesi örneği. Uşak Üniversitesi Sosyal Bilimler Dergisi, 3(1), 32-49.

Bektaş, M., Okur, A., \& Karadağ, B. (2014). İlkokul ve ortaokul son sınıf öğrencilerinde metaforik alg1 olarak kitap. Türk Kütüphaneciliği Dergisi, 28(2),154-168.

Biçer, N., \& Alan, Y. (2017). Türkçe öğretmeni adaylarının kitap okuma alışkanlıklarının genel öz yeterlikleri üzerindeki etkisi. Erzincan Eğitim Fakültesi Dergisi, 19(1), 100-116.

Bozan, A. (2012). Hizlı okuma eğitiminin 10. sinıf öğrencilerinin okuma hızlarına ve anlama düzeylerine etkisi. Yüksek Lisans Tezi. Çanakkale: Çanakkale On Sekiz Mart Üniversitesi.

Bozpolat, E. (2015). Türkçe öğretmen adaylarının dört temel dil becerisine ilişkin metaforik algıları. Turkish Studies, 10(11), 313-340.

Calp, M. (2010). Özel ĕgitim alanı olarak Türkçe öğretimi. Ankara: Nobel Yayıncılık.

Cerit, Y. (2008). Öğrenci, öğretmen ve yöneticilerin müdür kavramı ile ilgili metaforlara ilişkin görüşleri. Eğitim ve Bilim, 3(147), 3-13.

Coşkun, E. (2002). Lise 2. sinıf öğrencilerinin sessiz okuma hızlart ve okuduğunu anlama düzeyleri üzerine bir araştırma. Yüksek Lisans Tezi. Ankara: Gazi Üniversitesi.

Coşkun, M. (2010). Lise öğrencilerinin "iklim” kavramıyla ilgili metaforları (zihinsel imgeleri). Turkish Studies, 5(3), 919-940.

Çelikten, M. (2006). Kültür ve öğretmen metaforları. Erciyes Üniversitesi Sosyal Bilimler Enstitüsü Dergisi, 1(21), 269-283.

Çiftçibaşı, M. C. (2013). Huzlı okuma teknikleri eğitiminin müzik eğitiminde deşifre becerisine etkisi. Doktora Tezi. Burdur: Mehmet Akif Ersoy Üniversitesi.

Dedebali, N. C. (2008). Hızlı okuma tekniğinin sekizinci sınıf öğrencilerinin okuma hızlarına ve okuduğunu anlama düzeylerine etkisi. Yüksek Lisans Tezi. Aydın: Adnan Menderes Üniversitesi.

Döğüşgen, M. M. (2017). Çocuklar için anlayarak hızlı okuma teknikleri. İstanbul: Ekinoks Yayınevi.

Dündar, H., \& Karaca, E. T. (2013). Formasyon öğrencilerinin pedagojik formasyon programına ilişkin sahip oldukları metaforlar. Gazi Üniversitesi Endüstriyel Sanatlar Eğitim Fakültesi Dergisi, 30, 19-34.

Ekici, G. (2016). Biyoloji öğretmeni adaylarının mikroskop kavramına ilişkin algılarının belirlenmesi: Bir metafor analizi çalışması. Ahi Evran Üniversitesi Kırşehir Ĕ̌gitim Fakültesi Dergisi, 17(1), 615-636.

Ekiz, D., \& Koçyiğit, Z. (2013). Sınıf öğretmenlerinin "öğretmen" kavramına ilişkin metaforlarının tespit edilmesi. Kastamonu Ĕ̆itim Dergisi, 21(2), 439-458.

Eraslan, L. (2011). Sosyolojik metaforlar. Akademik Bakış Dergisi, 27, 1-22.
Erdoğan, T., \& Erdoğan, Ö. (2013). A metaphor analysis of the fifth grade students' perceptions about writing. AsiaPacific Education Researcher, 22(4), 347-355.

Geçit, Y., \& Gencer, G. (2011). Sınıf öğretmenliği 1. sınıf öğrencilerinin coğrafya algılarının metafor yoluyla belirlenmesi (Rize Üniversitesi örneği). Marmara Coğrafya Dergisi, 23, 1-19.

Girmen, P. (2007). Ilköğretim ögrrencilerinin konuşma ve yazma sürecinde metaforlardan yararlanma durumlarl. Doktora Tezi. Eskişehir: Anadolu Üniversitesi.

Gündüz, O., \& Şimşek, T. (2011). Anlama teknikleri-1: Uygulamalı okuma eğitimi el kitabı. Ankara: Grafiker Yayınları.

Güneş, F. (2009). Hızlı okuma ve anlamı yapılandırma. Ankara: Nobel Yayıncılık.

Güveli, E., İpek, A. S., Atasoy, E., \& Güveli, H. (2011). Sınıf öğretmeni adaylarının matematik kavramına yönelik metafor algiları. Turkish Journal of Computer and Mathematics Education, 2(2), 140-159.

Kaçar, K. (2015). Hızlı okuma ĕgitiminin ortaokul 7. sınıf öğrencilerinin okuduğunu anlama becerilerine ve okumaya ilişkin tutumlarına etkisi. Yüksek Lisans Tezi. Elazı ğ: Fırat Üniversitesi.

Karakuş, N., \& Baki, Y. (2014). Türkçe öğretmeni adaylarının kitap okuma alışkanlıklarının çeşitli değişkenler açısından incelenmesi. International Journal of Language Academy, 2(3), 74-87.

Karakuş, N., \& Kozçetin, K. (2016). Türkçe öğretmeni adaylarının okuma kavramına yönelik metaforik algılarının incelenmesi. Mehmet Akif Ersoy Üniversitesi Eğitim Fakültesi Dergisi, 40, 387-404.

Karatay, H. (2014). Okuma eğitimi: Kuram ve uygulama. Ankara: Pegem Yayınları.

Kayalan, M. (2000). Etkili ve hizlı okuma. İstanbul: Alfa Basım Yayım.

Keskin, H. K., \& Akyol, H. (2014). Yapılandırılmış okuma yönteminin okuma hızı, doğru okuma ve sesli okuma prozodisi üzerindeki etkisi. Ana Dili Eğitimi Dergisi, 2(4), 107-119.

Keskin, T. (2015). Hızlı okuma. İstanbul: AZ Kitap.

Koç, E. S. (2014). Sınıf öğretmeni adaylarının öğretmen ve öğretmenlik mesleği kavramlarına ilişkin metaforik algıları. İönü Üniversitesi Ĕgitim Fakültesi Dergisi, 15(1), 47-72.

Koçak, B., Çermik, F., Polat, S., \& Şahin, N. (2016). Öğretmen adaylarının kitap okuma tutumlarının çeşitli değişkenler açısından incelenmesi. Uluslararası Türkçe Edebiyat Kültür Eğitim Dergisi, 5(1), 395-411.

Komisyon (2014). Pedagojik formasyon için ögretim ilke ve yöntemleri. Ankara: Anı Yayıncılık.

Kondu, C. (2010). Hozlı okuma. İstanbul: Akis Kitap.

Köksal, Ç., Erginer, E., \& Baloğlu, M. (2016). İlkokul birinci sınıf öğrencilerinin okuma ve yazmaya yükledikleri anlamlar: Bir metafor analizi çalışması. Gaziosmanpaşa 
Üniversitesi Sosyal Bilimler Araştırmaları Dergisi, 11(1), 133-156.

Köksal, O., \& Atalay, B. (2016). Ö̆gretim ilke ve yöntemleri. Konya: Eğitim Yayınevi.

Kurudayığlu, M., \& Çelik, G. (2013). Türkçe öğretmeni adaylarının okumaya ve okuma eğitimine ilişkin özyeterlik algıları. Uşak Üniversitesi Sosyal Bilimler Dergisi, 6(4), 109-138.

Lüle-Mert, E. (2013). Türkçe öğretmen adaylarının dört temel dil becerisine ilişkin algılarının metaforlar aracılığıyla analizi. Uluslararası Sosyal Araştırmalar Dergisi, 6(27), 357-372.

Maviş, A. (2011). Anlayarak hızlı okuma ve ögrenme teknikleri. İstanbul: Yediveren Yayınları.

Merriam, S. B. (2013). Nitel araştırma: Desen ve uygulama için bir rehber. (Çev. Ed. S. Turan). Ankara: Nobel Yayıncılık.

Modell, A. H. (2009). Metaphor-the bridge between feelings and knowledge. Psychoanalytic Inquiry, 29 (1), 6-11.

Müldür, M., \& Çevik, A. (2017). Ortaokul öğrencilerinin yazma becerisine ilişkin algıları: Bir metafor analizi çalışması. SDU International Journal of Educational Studies, 4(2), 54-70.

Palmquist, R. A. (2001). Cognitive style and users metaphors for the exploratory study. Journal of Academic Librarianship, 27 (1), 24-32.

Pilav, S., \& Elkatmış, M. (2013). Öğretmen adaylarının Türkçe kavramına ilişkin metaforları. Turkish Studies, 8(3), 1207-1220.

Ruşen, M. (2016). Hızlı okuma. İstanbul: Alfa Basım Yayım.

Saban, A. (2008). İlköğretim I. kademe öğretmen ve öğrencilerinin bilgi kavramına ilişkin sahip oldukları zihinsel imgeler. Ilkögretim Online, 7(2), 421-455.

Saban, A. (2009). Öğretmen adaylarının öğrenci kavramına ilişkin sahip oldukları zihinsel imgeler. Türk Ĕ̈itim Bilimleri Dergisi, 7(2), 281-326.

Saracaloğlu, A., Dedebali, N. C., \& Karasakaloğlu, N. (2011). Sekizinci sınıf öğrencilerinin sessiz okuma hızları ve okuduğunu anlama düzeyleri. Ahi Evran Üniversitesi Kırşehir Eğitim Fakültesi Dergisi, 12(3), 177-193.

Soysal, T. (2015). Hızlı okuma tekniklerinin beşinci sınıf ögrencilerinin okuma hızlarına ve anlama düzeylerine etkisi. Yüksek Lisans Tezi. Bolu: Abant İzzet Baysal Üniversitesi.

Sterenberg, G. (2008). Investigating teachers' images of mathematics. Journal of Mathematics Teacher Education, 11, 89-105.

Susar-Kırmızı, F., \& Çelik, D. (2015). İlkokul öğrencilerinin ilkokuma yazma öğrenme sürecine ilişkin metafor alg1lar1. Turkish Studies, 10(10), 793-816.

Şahin, A. (2016). İlkokul öğrencilerinin bitişik eğik ve dik temel harfler ile yazılmış metinleri okuma hızlarının karşılaştırılması. Turkish Studies, 11(3), 2081-2094.
Şahin, Ç. (2010). Verilerin analizi. Remzi Y. Kıncal (Ed.), Bilimsel araştırma yöntemleri içinde, (ss. 181-217). Ankara: Nobel Yayıncılik.

Şahin, Y. (2011). Okuma ĕgitimi. Konya: Eğitim Kitabevi.

Taşdemir, M. (2013). Kuramdan uygulamaya ögretim ilke ve yöntemleri. Ankara: Edge Akademi.

Taşgın, A., \& Köse, E. (2016). Sınıf öğretmeni adaylarının hedef ve değerlendirme kavramlarına ilişkin metaforları. Hacettepe Üniversitesi Eğitim Fakültesi Dergisi, 30(3), 116-130.

Tiryaki, E. N., \& Demir, A. (2016). Türkçe öğretmeni adaylarının yazma becerisine yönelik metaforik algıları. Mustafa Kemal Üniversitesi Sosyal Bilimler Enstitüsü Dergisi, 13-33, 18-27.

Topçuoğlu-Ünal, F., \& Tekin, M. T. (2013). Eleştirel yazmaya ilişkin Türkçe öğretmeni adaylarının metaforik algilar1. Turkish Studies, 8(13), 1595-1606.

Tunalı, M. (2010). Anlayarak hızlı okuma ve ögrenme. İstanbul: Yakamoz Yayınları.

Ulusoy, M. (2013). Sınıf öğretmeni adaylarının Türkçe ve öğrenme alanları ile ilgili metaforları. Akdeniz Eğitim Araştırmaları Dergisi, 14, 1-18.

Ün-Açıkgöz, K. (2007). Aktif ögrenme. İzmir: Biliş Özel Eğitim Danışmanlık Yayınları.

Ünal, F. (2017). Okul öncesi öğretmen adaylarının "oyun” kavramına ilişkin metaforik algıları. Route Educational and Social Science Journal, 4(5), 407-426.

Ünalan, Ş. (2006). Türkçe öğretimi. Ankara: Nobel Yayıncilık.

Wardani, S. (2014). Using speed reading and extensive reading activities to improve students' reading fluency. Jurnal Pendidikan Humaniora, 2(3), 219-227.

Woollard, J. (2005). The implications of the pedagogic metaphor for teacher education in computing. Technology, Pedagogy and Education, 14(2), 189-204.

Yalçın, A., Erdoğan-Çeltik, S., \& Altınok, Ş. (2017). Hukuk fakültesi öğrencilerinin hızlı okuma becerilerinin değerlendirilmesi. Ahi Evran Üniversitesi Kırşehir Ĕ̈itim Fakültesi Dergisi, 18(3), 100-114.

Yalçın, M., \& Erginer, A. (2012). İlköğretim okullarında okul müdürüne ilişkin metaforik algılar. Öğretmen Eğitimi ve Eğitimcileri Dergisi, 1(2), 229-256.

Yalçın, M., Aydoğdu-Özoğlu, E., \& Dönmez, A. (2016). Öğretim elemanlarının araştırma görevlisi kavramına ilişkin metaforik algıları. Ĕgitim ve Bilim, 41(185), 1932.

Yıldırım, A., \& Şimşek, H. (2011). Sosyal bilimlerde nitel araştırma yöntemleri. Ankara: Seçkin Yayıncılık.

Yob, I. M. (2003). Thinking constructively with metaphors. Studies in Philosophy and Education, 22, 127-138. 